\title{
Analysis of microbial community in Japanese vineyard soils by culture-independent molecular approach
}

This article was published in the following Dove Press journal:

International Journal of Wine Research

18 September 2010

Number of times this article has been viewed

\author{
Keiko Fujita \\ Seiichi Furuya \\ Minako Kohno \\ Shunji Suzuki \\ Tsutomu Takayanagi \\ Institute of Enology and Viticulture, \\ University of Yamanashi, Kofu, \\ Yamanashi, Japan
}

Correspondence: Shunji Suzuki Institute of Enology and Viticulture, University of Yamanashi, I-I3-I Kitashin, Kofu, Yamanashi, Japan

Tel +8I 552208394

Fax +8I 552208768

Email suzukis@yamanashi.ac.jp

\begin{abstract}
Soil microbes play an important role in the management of soil environment. They form various microbial communities in response to environmental factors, including soil texture and chemical components. Because of this, it is difficult to determine the microbial community structure of soil. In vineyard soils, the overall microbial community structure has yet to be unraveled. To understand the microbial community in vineyard soil, we surveyed comprehensively microbial communities in Japanese vineyard soils by using a culture-independent molecular approach. We identified 681 fungal clone sequences and 1076 bacterial clone sequences in soil samples collected from nine independent Japanese vineyards, and the results suggested that Ascomycota is the dominant group in the fungal community, whereas Proteobacterium and Acidobacterium are the dominant groups in the bacterial community. DNA was directly extracted from the soil samples, and the fungal internal transcribed spacer 1 (ITS 1) region or the bacterial $16 \mathrm{~S}$ ribosomal DNA (rDNA) region was amplified by polymerase chain reaction. The recovered fungal clones were sorted into 225 operational taxonomic units and the majority of the clone sequences were assigned to Ascomycota. Meanwhile, the recovered bacterial clones were sorted into 17 phyla, and the abundant phyla were Proteobacterium and Acidobacterium. These results differed from the reported fungal and bacterial community structures in forest and agricultural soils. Moreover, we preliminarily generated a catalog of Japanese vineyard soils. The microbial community structures in the vineyard soils were extremely complex, suggesting that the microbial community structure in each vineyard soil has individual characteristics. Our study comprehensively showed for the first time fungal and bacterial community structures in Japanese vineyard soils, and is most likely to provide a clue to understand the nature of Japanese vineyard soils.
\end{abstract}

Keywords: Japanese vineyard, soil microbe, microbial community structure, 16S rDNA

\section{Introduction}

Soil microbes play an important role in the soil ecosystem, including formation of soil structure, decomposition of organic compounds, detoxification of toxins, and cycling of carbon, nitrogen, phosphorus, and sulfur. ${ }^{1}$ Some soil microbes sustain and stimulate plant growth and suppress several diseases caused by soil-borne plant pathogens. ${ }^{1}$ In addition, because soil microbial community structure is altered by environmental and anthropogenic factors, ${ }^{2}$ its use as an indicator of soil quality has been proposed. ${ }^{3}$

Soil microbial communities have been assessed conventionally by culturebased methods. ${ }^{4,5}$ However, current culture techniques can culture less than $1 \%$ of environment-dwelling microbes from any experimental sources. ${ }^{6}$ Although culturebased methods allow for the isolation of microbial colonies, spores and/or hyphae, they 
present no clues to understanding exhaustively the microbial community structures in environmental sources. On the other hand, uncultured microbes have been investigated by molecular techniques, including polymerase chain reaction (PCR) and real-time polymerase chain reaction (RT-PCR), using DNA or RNA isolated from environmental sources. ${ }^{7,8}$ To understand the variation and/or composition of microbial community structures or microbial diversities, PCR products are subjected to fingerprinting techniques, including denaturing or temperature gradient gel electrophoresis, terminal restriction fragment length polymorphism, and automated ribosomal intergenic spacer analysis (ARISA). ${ }^{1,9}$ Using molecular techniques, microbial communities, and diversities in soils collected from grasslands, forests, alpine areas, and farms have been identified and the effects of chemical component, ${ }^{10}$ soil particle size,${ }^{11}$ cultivated plant, ${ }^{12}$ seasonal condition, ${ }^{13,14}$ and agricultural management system ${ }^{15,16}$ on the diversity of soil microbes have been evaluated.

It is important for grape growers and winemakers to understand vineyard soil to satisfy the demand for high fruit yield, improved wine style, and superb wine quality. Books on soil for fine wines are available. ${ }^{17,18}$ However, there are few descriptions in those books about microbes (fungi and bacteria) in vineyard soils, although soil microbes play an important role in the management of soil environment. Microbial communities in vineyard soils may be unique compared with those in soils of other agroecosystems, because vineyards are generally subjected to less frequent tillage, less nitrogen fertilization, and less herbicide application. ${ }^{19}$ In addition, several farming practices may influence microbial communities in vineyard soils. For example, compost amendment induced the alteration and resilencing of microbial community in vineyard soil. ${ }^{20}$ In a pinot noir vineyard, microbial communities were also altered by soil morphology, soil depth, and grapevine root. ${ }^{19}$ However, in those two studies, an exhaustive evaluation of microbial diversities at the level of fungal species or phylogenetic bacterial taxa was not conducted because those studies were based on the evaluation by the phospholipid ester-linked fatty acid method. Currently, copper concentrations resulting from the use of fungicides and fertilizers are increasing in vineyard soil surface, and this trend is raising concern as regards its harmful and irreversible effects on the soil ecosystem. ${ }^{21}$ Thus, it is important to monitor the status of soil microbial population and diversity. Dell'Amico et $\mathrm{al}^{21}$ investigated ex-vineyard soil by the denaturing gradient gel electrophoresis method and identified copper-tolerant bacteria as the indicator of copper pollution in the soil. One study of the effects of copper contamination on the microbial community in vineyards employed ARISA, and the findings suggested that bacterial genetic structure in nonamended soil varied significantly and Actinobacteria are the prevalent bacteria in coppercontaminated nonamended soil. ${ }^{22}$ In vineyard soils, however, the microbial community structure and the microbial species have not been comprehensively evaluated and are thus little understood. In Japan, no studies have been conducted on the microbial communities in vineyard soils. To improve Japanese viticulture and sustain vineyard soil environment, we tried to gain an overview of soil characteristics and microbial species in vineyard soils. For this purpose, soils were collected from some vineyards and the fungal internal transcribed spacer 1 (ITS 1) region or the bacterial 16S ribosomal DNA (rDNA) region was PCR-amplified to understand the microbial communities.

\section{Materials and methods Soil samples}

To survey microbes in Japanese vineyard soils, we obtained 31 soil samples from nine vineyards. Four soil samples were obtained from pits located approximately 3-4 $\mathrm{m}$ apart in the experimental vineyard of The Institute of Enology and Viticulture, University of Yamanashi, Japan, in January 2010 (sample names K1-K4). Seven soil samples were obtained from seven commercial vineyards in Japan (A, B, C, D, E, F, and G), and 20 soil samples were obtained from two pits in the experimental vineyard of The Institute of Enology and Viticulture, University of Yamanashi, Japan, from May 2008 to December 2008 (BK3-BK12 and BC3-BC12). Soil pits located at a distance of $50 \mathrm{~cm}$ from each grapevine trunk were dug to a depth of $30 \mathrm{~cm}$. Approximately $50 \mathrm{~g}$ of soil sample was taken from each pit. The properties of the soil samples are summarized in Table 1.

\section{Soil texture analysis}

Soil particle size was measured according to the Colorado State University Master Gardener manual. ${ }^{23}$ Briefly, approximately $20 \mathrm{~g}$ of soil from which rocks and root tips were removed was strongly shaken in $40 \mathrm{~mL}$ of water for $15 \mathrm{~min}$ utes. Then, the soil particles were allowed to stand for one month. By measuring the thicknesses of sand, silt, and clay layers, the percentages of sand, silt, and clay were calculated. Soil texture was identified with a soil textural triangle.

\section{$\mathrm{pH}$ and electrical conductivity of soil}

Approximately $20 \mathrm{~g}$ of soil was strongly shaken in $100 \mathrm{~mL}$ of water for 10 minutes and the mixture was left to stand for 10 minutes. $\mathrm{pH}$ and electrical conductivity were measured 
Table I Summary of sampling locations and physical and chemical properties of soils

\begin{tabular}{|c|c|c|c|c|c|c|}
\hline $\begin{array}{l}\text { Library } \\
\text { name }\end{array}$ & Description & Site & $\begin{array}{l}\text { Cultivated } \\
\text { vine }\end{array}$ & Soil texture & $\mathbf{p H}$ & $\begin{array}{l}\text { EC } \\
(\mu \mathrm{S} / \mathrm{cm})\end{array}$ \\
\hline $\mathrm{KI} \sim \mathrm{K} 4^{\mathrm{a}}$ & Conventional agriculture (Cover crops) & Kofu & $\mathrm{CS}^{\mathrm{c}}$ & Clay loam & 6.8 & 14.3 \\
\hline A & Hardly use Bordeaux & Koshu & Koshu & Loamy sand & 7.6 & 51 \\
\hline B & Conventional agriculture & Koshu & Koshu & Clay & 6.9 & 86 \\
\hline C & Biodiversity & Koshu & CS & Sandy loam & 7.0 & 60 \\
\hline D & Cover crops & Ibuki & CS & Sand & 6.6 & 12 \\
\hline$E$ & Sampling right after replant & Koshu & Koshu & Clay & 7.4 & 25 \\
\hline $\mathrm{F}$ & Cover crops & Koshu & CS & Clay & 7.1 & 43 \\
\hline G & Conventional agriculture & Ibuki & Koshu & Sandy loam & 7.3 & 102 \\
\hline $\mathrm{BK} 3 \sim \mathrm{BK} \mid 2^{\mathrm{b}}$ & Conventional agriculture (Cover crops) & Kofu & Koshu & Sandy loam & $6.2-7.7$ & $39-93$ \\
\hline $\mathrm{BC} 3 \sim \mathrm{BCl} 2^{\mathrm{b}}$ & Conventional agriculture (Cover crops) & Kofu & CS & Sandy loam & $6.8-7.4$ & $32-96$ \\
\hline
\end{tabular}

Notes: ${ }^{2}$ Four clone libraries for soils sampled from four pits at vineyard K; bseasonal clone libraries for soil sampled from one vineyard monthly from March to December; cCabernet Sauvignon.

with a $\mathrm{pH}$ and electrical conductivity tester (Combol; HANNA Instruments, Padova, Italy).

\section{DNA extraction from soil and preparation of clone library}

Soils from each pit were mixed and large rocks and root tips were removed. Total DNA was directly extracted from 0.4-0.3 g of soil using a PowerMax ${ }^{\mathrm{TM}}$ Soil DNA Isolation Kit (MO BIO Laboratories, Inc., Carlsbad, CA) according to the manufacturer's instructions. PCR amplification of fungal ITS 1 region or bacterial 16S rDNA region was performed using an ITS primer pair (5'-GTAACAAGGTTTCCGT-3' and $5^{\prime}$-CGTTCTTCATCGATG-3') or a $16 \mathrm{~S}$ primer pair ( $5^{\prime}$-AGAGTTTGATCCTGGCTCAG- $3^{\prime}$ and 5'-GTATTACCGCGGCTGCTG-3'), respectively. The PCR reaction mix consisted of $1 \mu \mathrm{L}$ of $10 \times$ PCR buffer, $0.4 \mu \mathrm{L}$ of $2.5 \mathrm{mM}$ each dNTP, $0.25 \mu \mathrm{L}$ of $20 \mathrm{mM}$ each primer, $0.1 \mu \mathrm{L}$ of Hot Start Taq polymerase (Takara, Shiga, Japan), $1 \mu \mathrm{L}$ of DNA solution, and $7 \mu \mathrm{L}$ of $\mathrm{ddH}_{2} \mathrm{O}$. PCR conditions were as follows: $95^{\circ} \mathrm{C}$ for three minutes (one cycle); $95^{\circ} \mathrm{C}$ for 20 seconds, $55^{\circ} \mathrm{C}$ for 30 seconds, and $72^{\circ} \mathrm{C}$ for 30 seconds (20, 22, or 24-27 cycles for fungal ITS 1 region, 14, 15, 18 , or 28 cycles for bacterial $16 \mathrm{~S}$ rDNA region); and $72^{\circ} \mathrm{C}$ for five minutes (one cycle). PCR cycles were controlled to prevent saturation of amplified PCR products. The PCR products were separated on $1.5 \%$ agarose gels. Agarose gels at 250-500 base pairs (bp) for fungal ITS or 450-800 bp for bacterial 16S rDNA were excised and the PCR products were extracted with a QIAquick Gel Extraction Kit (Qiagen, Valencia, CA) according to the manufacturer's instructions. After extraction, the products were ligated to $\mathrm{p}-\mathrm{TAC}-1$ vector (Bio Dynamics Laboratory Inc., Tokyo, Japan) or pMD20-T vector (Takara, Shiga, Japan). By transforming the ligation product into Escherichia coli JM109 strain, fungal ITS clone, and bacterial 16S rDNA clone libraries were constructed. DNA extractions from samples K1-K4 were used for the analysis of fungal community. K1-K4 clone libraries were generated from three replicates of one soil sample. Meanwhile, DNA extractions from samples A-G were used for the analysis of fungal and bacterial communities. The remaining samples, BK3-BK12 and BC3-BC12, were used for the analysis of bacterial community.

\section{Sequence analysis}

Sequencing of libraries was accomplished by DyeDeoxy terminator cycle sequencing with M13 forward or reverse primer. DNA sequences were subjected to a homology search using the BLAST search program. ${ }^{24}$ Based on BLAST search results, fungal ITS clones were sorted into operational taxonomic units (OTUs). Fungal ITS clones in OTU have $>98 \%$ sequence similarity. We confirmed the appropriate group using phylogenetic trees that were constructed with the neighbor-joining method of Molecular Evolutionary Genetics Analysis software, ${ }^{25}$ although we do not show the phylogenetic trees. After BLAST search, bacterial 16S rDNA clone sequences were assembled into phylum groups using Classifier of Ribosomal Database Project (RDP-X). ${ }^{26}$

\section{Nucleotide sequence accession numbers}

We have submitted all nucleotide sequence data to DDBJ database.

\section{Results}

\section{Sequence analysis of fungal ITS clones}

A total of 103 clones from K1, 86 clones from K2, 89 clones from K3, and 87 clones from $\mathrm{K} 4$ were recovered. Clones from plant ITS region sequences were included in the ITS libraries because the designed primer pair also amplified 
the plant ITS region. Eventually, $81 \mathrm{~K} 1$ clones, $85 \mathrm{~K} 2$ clones, $62 \mathrm{~K} 3$ clones, and $73 \mathrm{~K} 4$ clones were examined for their similarity to a sequence from a known fungus in the database (Table 2). Clone sequences with BLAST scores exceeding 200 (100\%-81\% identity) were $70 \mathrm{~K} 1$ clones (86.4\%), $71 \mathrm{~K} 2$ clones $(83.5 \%), 32 \mathrm{~K} 3$ clones $(51.6 \%)$, and $62 \mathrm{~K} 4$ clones $(84.9 \%)$. K1-K4 clone libraries consisted of $49,38,33$, and 40 OTUs, respectively (Table 2), and the obtained 303 clone sequences from K1-K4 were sorted into 109 different OTUs. These results suggested that this molecular method was able to detect many fungal species in vineyard soils. The fungal ITS clone libraries from samples $\mathrm{K} 1-\mathrm{K} 4$ had individual structures that consisted of unique and variously sized OTUs, although the clone libraries were generated from different pit soils collected from the same vineyard (Table 3, Supplementary Table 1). For example, the most abundant OTU (uncultured fungus) in $\mathrm{K} 1$ and $\mathrm{K} 2$ clone libraries was composed of 10 and 21 clones, respectively, while in K3 and K4 clone libraries, the OTU was represented by a single clone. OTU 83 (unidentified sequence) that included 11 clones was the largest OTU in K3 clone library while the clone sequences of the other libraries were not assigned to this OTU. The clone sequences of $\mathrm{K} 1-\mathrm{K} 4$ clone libraries were included in OTUs 3, 30, and 107. Moreover, 27.5\% of K1-K4 OTUs were represented by the clone sequences from the above two clone libraries. These results suggest that fungi in vineyard soils do not have a uniformly distributed community structure.

To survey fungi in Japanese vineyard soils, we also examined fungi of seven soils sampled from other vineyards (vineyards A-G). A total of 516 clones were recovered and 380 clones $(73.6 \%)$ resulted in successful fungal sequences. These clone sequences were of fungal origin and comprised

Table 2 Number of sequences and operational taxonomic units recovered from each fungal clone library

\begin{tabular}{lll}
\hline $\begin{array}{l}\text { Library } \\
\text { name }\end{array}$ & $\begin{array}{l}\text { No. of } \\
\text { sequences }\end{array}$ & $\begin{array}{l}\text { No. of } \\
\text { OTUs }\end{array}$ \\
\hline KI & 81 & 49 \\
K2 & 85 & 38 \\
K3 & 62 & 33 \\
K4 & 73 & 40 \\
A & 56 & 21 \\
B & 57 & 25 \\
C & 53 & 10 \\
D & 56 & 21 \\
E & 46 & 27 \\
F & 54 & 28 \\
G & 58 & 32 \\
\hline
\end{tabular}

157 OTUs. Finally, we obtained and determined 681 clone sequences that were included in 225 OTUs in soils from eight vineyards, namely, samples A-G and K1-K4. The results of BLAST search of these clones are shown in Supplementary Table 1. The majority of the fungal ITS clone sequences were assigned to Ascomycota (30.8\%) and unclassified fungi (38.2\%, Figure 1A). The remaining clones were assigned to Basidiomycota (9.5\%), Zygomycota (3.7\%), Glomeromycota $(2.5 \%)$, and Oomycetes $(3.5 \%)$. Together, the results suggest that various kinds of Ascomycota fungi exist in the vineyard soils.

The fungal community structures were very complex in the seven vineyard soils as well as in the four pit soils taken from one vineyard, because common OTUs were rarely found in the seven vineyard clone libraries. By comparing the clone libraries of vineyards $\mathrm{K}, \mathrm{A}, \mathrm{B}, \mathrm{C}, \mathrm{D}, \mathrm{E}, \mathrm{F}$, and $\mathrm{G}$, we found original OTUs in the clone libraries of vineyards $\mathrm{C}$ and $\mathrm{D}$. The clone library of vineyard C consisted of few OTUs included many clones, such as Aspergillus spp., Aureobasidium pullulans, Phomopsis sp., while the clone library of vineyard D had many unique OTUs (Table 2, Supplementary Table 1). Thus, soils of vineyards C and D may have original fungal community structures although we did not conduct further assessment because of the small sample size and the complete lack of replication at vineyards $\mathrm{A}-\mathrm{G}$.

\section{Sequence analysis of bacterial I6S rDNA clones}

To survey bacterial community structures in vineyard soils in a manner similar to the fungal community structures, 407 clones were recovered from the seven vineyards. To determine widespread bacterial community in vineyard, we sampled two pit soils from one vineyard monthly from May 2008 through December 2008, and 846 clones were recovered because of significant seasonal changes of the bacterial community, as reported by Lipson and Schmidt. ${ }^{14}$ Clones whose sequences were amplified by an unpaired primer were omitted from the clone library. Finally, we searched 1106 clone sequences in the National Center for Biotechnological Information (NCBI) database. Database sequences yielding the highest percentage identity to the clone sequences were chosen as the best match for the clones. The results that matched sequences in the NCBI database are shown in Supplementary Table 2, and $16 \mathrm{~S}$ rDNA gene sequences with $>97 \%$ similarity are considered to be the same species in phylogenetic position. However, as 30 clone sequences were not listed in the NCBI database and could not be sorted into "bacteria" by Classifier of RDP-X, those clones were omitted from the clone library 
Table 3 Fungal species from BLAST search with the highest sequence identity to some large OTUs and distribution of operational taxonomic units in $\mathrm{KI}-\mathrm{K} 4$

\begin{tabular}{|c|c|c|c|c|c|c|c|c|c|}
\hline OTU & Blast match & Accession no. & $\begin{array}{l}\text { ITS size } \\
\text { (bp) }\end{array}$ & $\begin{array}{l}\text { Identity } \\
\text { (\%) }\end{array}$ & $\mathbf{K} \mathbf{I}$ & $\mathbf{K 2}$ & $\mathbf{K 3}$ & K4 & $\begin{array}{l}\text { Total No. } \\
\text { of clone }\end{array}$ \\
\hline 3 & Uncultured mycorrhizal fungus & AB4544II & 237 & $100-99$ & 4 & 2 & 1 & 3 & 10 \\
\hline 23 & Uncultured Basidiomycota & AY970109 & 240 & 99 & I & & 1 & 7 & 9 \\
\hline 25 & Uncultured Ceratobasidiaceae & DQ182419 & 231 & $96-95$ & & 3 & 2 & 7 & 9 \\
\hline 30 & Pythium sylvaticum & DQ52874I & 346 & $100-99$ & 4 & 5 & 2 & 2 & 13 \\
\hline 40 & Uncultured zygomycete & EU490044 & 213 & $85-84$ & 4 & 8 & & & 12 \\
\hline 54 & Unidentified $^{\mathrm{a}}$ & - & 213 & - & 5 & & 9 & I & 15 \\
\hline 57 & Ceratobasidium sp. & FJ435I47 & 234 & $100-99$ & & & & 4 & 4 \\
\hline 80 & Uncultured fungus & FJ78I42I & 245 & 97 & & & & 5 & 5 \\
\hline 83 & Unidentified & - & 426 & - & & & II & & II \\
\hline 85 & Unidentified & - & 249 & - & & & 4 & 1 & 5 \\
\hline 96 & Uncultured fungus & GQ866220 & 220 & $100-99$ & 4 & 6 & & & 10 \\
\hline $107^{\mathrm{b}}$ & Uncultured fungus & GU370749 & 211 & $100-99$ & 10 & 21 & I & I & 33 \\
\hline
\end{tabular}

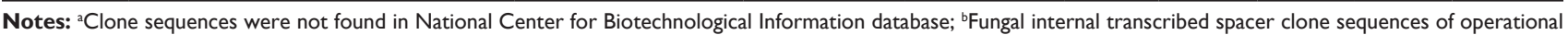
taxonomic unit I07 had closest identity to GU370749, GQ50933I, GQ5095I9, GQ5I09I0, GQ5II388, GQ5I5874, GQ523707, but most clone sequences were matched to GU370749.

and Supplementary Table 2. It was uncommon that more than three clone sequences were assigned to the same accession number, with the exception of "uncultured bacterium (FJ479014)" that was found in BK10, BK11, BK12, BC10, $\mathrm{BC} 11$, and BC12. BLAST search demonstrated that $80.6 \%$ of the 1076 clone sequences had high similarity to members of yet undescribed bacterial divisions. To sort the "unclassified" clones, we used Classifier of RDP-X (confidence threshold $=80 \%$ ). This resulted in sorting into 18 groups that included "unclassified bacteria". The most abundant phylum was Proteobacteria, which consisted of $23.1 \%$ of the total clones (Figure 1B). The second most abundant group was "unclassified bacteria" (22.1\%) and the third largest group was Acidobacteria (21.9\%). Other relatively large groups were Actinobacteria (8.1\%), Bacteroidetes (5.2\%), Chloroflexi (4.0\%), Gemmatimonadetes (3.2\%), Planctomycetes (3.1\%), and Verrucomicrobia (6.5\%). The percentage abundance of these groups varied for each clone library, although the number of clones was not sufficient to compare with the percentage abundance of phylum within one clone library. However, bacterial clone libraries other than the clone libraries of soil collected from September 2008 to December 2008 constantly
A

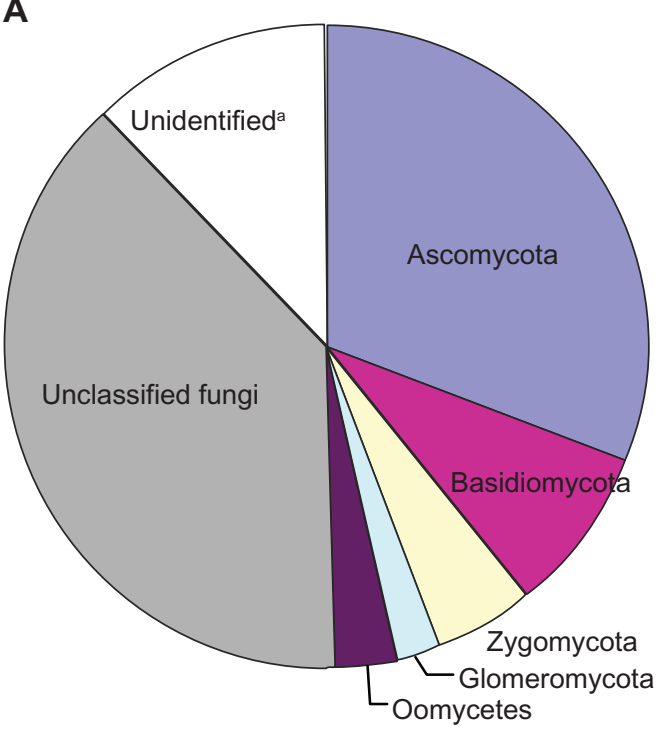

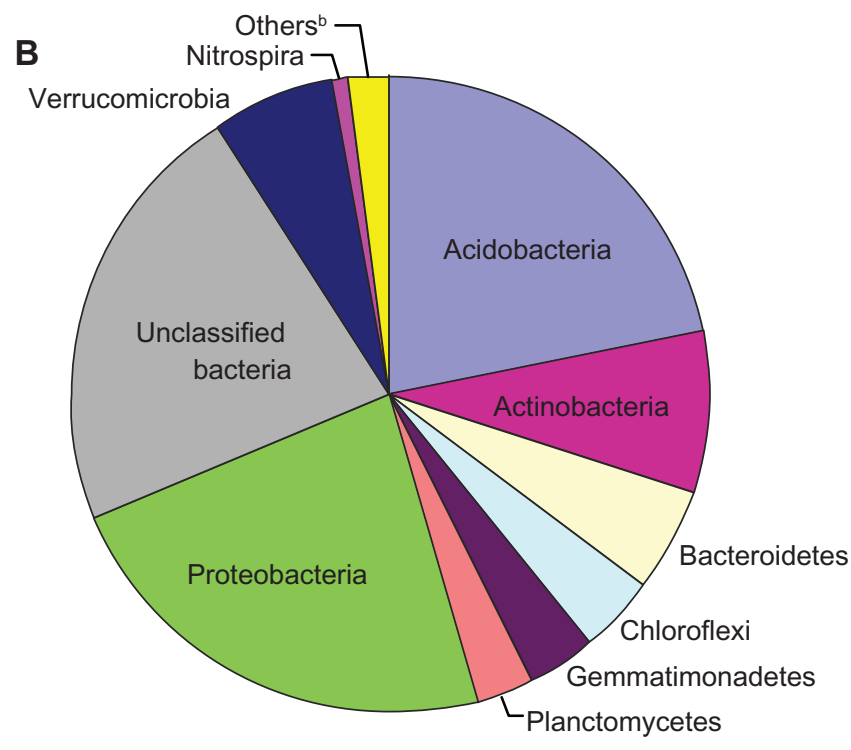

Figure I Frequencies of fungal ITS sequences belonging to each fungal phylum A and bacterial I6S rDNA sequences belonging to each bacterial phylum B. Fungal phyla were classified based on BLAST search results. Bacterial phyla were classified by using Classifier of RDP-X.

Notes: a Clone sequences were not found in NCBI database; 'others include Cyanobacteria, Firmicutes, Spirochaetes, ODI, OPI0, OPI I, TM7, and WS3. 
included Proteobacteria, Acidobacteria, and unclassified bacteria in abundance. The remaining phyla present within the clone libraries included Nitrospira, Cyanobacteria, Firmicutes, Spirochaetes, OD1, OP10, OP11, TM7, and WS3. Each consisted of less than $1 \%$ of the total clones.

\section{Discussion}

In this study, we determined fungal ITS and bacterial $16 \mathrm{~S}$ rDNA clone sequences in vineyard soils and showed the fungal and bacterial community structures in the soils. Previous reports have demonstrated the diversity and community structure of mycorrhizal fungi in vineyards ${ }^{27,28}$ and the variation in vineyard soil microbial communities influenced by compost amendment and increasing depth. ${ }^{19,20}$ WhitelawWeckert et $\mathrm{al}^{29}$ examined the effects of permanent swards and bare soil on soil microbial count in two Australian vineyards by culture methods. However, those studies did not determine the composition of fungi and bacteria at the species level in vineyard soils, and there are hardly any studies that deal with the comprehensive identification of clone sequences from vineyard soils. Thus, our study surveyed for the first time microbes present in vineyard soils. We recovered 109 OTUs from 303 fungal clone sequences of vineyard $\mathrm{K}$ clone libraries. As the rarefaction curves of the 303 fungal clones did not reach a plateau (data not shown), we were able to estimate only a small portion of fungi existing in the vineyard soils. We need to recover more clones to reveal the number of fungal species. Nevertheless, our results suggest that at least 109 fungal species exist in one vineyard and most of them belong to Ascomycota. These results have not been obtained in previous studies that used phospholipid esterlinked fatty acids or denaturing gradient gel electrophoresis to detect overall microbial community shifts and compare microbial community structures. ${ }^{30}$ The main Ascomycota detected by prosequencing analyses of forest soils consist of lichen-forming fungi, litter/wood decomposers, plant parasites, endophytes, and saprotrophs. ${ }^{31}$ The Ascomycota in our study may include fungal groups causing plant disease, endophytes, wood decomposers, and saprotrophs, because such fungi as Fusarium spp, ${ }^{32}$ Phomopsis spp, ${ }^{33}$ Aspergillus spp, ${ }^{34,35}$ Pezizomycotina spp, ${ }^{36}$ and Alternaria spp abound in fungal clone libraries.

We noted that the OTU patterns in the clone libraries and the number of clones within each OTU are very diverse even among the clone libraries from the same vineyard, suggesting the complex distribution of the fungal community. Unfortunately, it was impossible to identify the dominant fungus at the species level in the vineyard soils due to the limited sample size. However, we noticed that the species patterns of each clone library are interesting. Fungal clone libraries from vineyards $\mathrm{C}$ and $\mathrm{D}$ are the most unique among the eight vineyard clone libraries (Table 2, Supplementary Table 1). Microbial community structures are affected by environmental and anthropogenic factors. ${ }^{1}$ Vineyard $\mathrm{C}$ is managed with a biodynamic agricultural system (Table 1). The soil characteristics of vineyard D differ from those of other vineyards: the soil has a sandy texture, the highest acidity, and the lowest electrical conductivity (Table 1). It was shown that the compositions of bacterial communities in soils of biodynamic, conventional, and unfertilized agricultural management systems were vastly different although the clone libraries revealed similar diversities. ${ }^{15}$ Mäder et $\mathrm{al}^{37}$ found significantly higher microbial biomass and diversity in the soil of a biodynamic management system than in the soil of a conventional management system. Meanwhile, the effect of particle size on the microbial community structure was noted, in that small particles (silt and clay) yielded high microbial diversity compared with coarse particles (sand). ${ }^{11}$ A strong correlation between bacterial diversity and soil $\mathrm{pH}$ was also shown by Fierer and Jackson. ${ }^{38}$ Those reports agree with our results of fungal sequences and it seems that the characteristics of fungal community structures are reflected by soil environment and management. However, there was no obvious relationship between bacterial communities and environmental factors in vineyards $\mathrm{C}$ and $\mathrm{D}$ compared with fungal community structures in the same vineyards because each bacterial community was extremely complex and the variations in bacterial libraries might be restricted by the sample size. It is possible that the fungal community structure may be more sensitive to environmental factors than the bacterial community structure in vineyard soils. Further exhaustive studies are required to reveal the relationship between bacterial community structure and environmental factors.

Bates and Garcia-Pichel ${ }^{39}$ indicated that bacterial diversity was noticeably and significantly higher than fungal diversity. One gram of soil contains one to four billion bacteria and less than one billion fungi. ${ }^{40}$ Thus, to reveal the overall bacterial community structure in vineyard soil, it is necessary to conduct large-scale DNA sequence analysis. In this study, although we were not able to reveal the overall bacterial community structure, we were able to sort by phylum 1076 clone sequences recovered from samples collected monthly from one vineyard soil and from seven vineyard soils. We suggest that 17 of the 52 phyla determined exist in vineyard soils (see Figure 1B). ${ }^{41}$ Lejon et $\mathrm{al}^{22}$ showed that 30 clones derived from 
350-450 bp bacterial-ARISA bands from soil collected from a copper-contaminated vineyard belonged to Actinobacteria, Fibrobacteres, Gemmatimonadetes, and Proteobacteria. Our results indicated that bacteria from numerous phyla exist in vineyard soil. The major phyla of vineyard soil bacteria are Proteobacteria and Acidobacteria (Figure 1B). In forest soil, Proteobacteria and Bacteroidetes are the dominant bacterial groups, followed by Acidobacteria. ${ }^{42}$ In agricultural soils where maize and sugarcane are grown, phylum diversity is poor and the predominant groups are Actinobacteria, Bacteroidetes, and Fermicutes. ${ }^{42,43}$ Therefore, our results suggest that the microbial community structure in vineyard soil may be unique, in support of the work of Steenwerth et al. ${ }^{19}$ Meanwhile, the dominant fungal group in forest soils is Basidiomycota, ${ }^{31,44}$ and this dissimilarity in the dominant fungi also supported our suggestion. However, we do not know why Proteobacteria and Acidobacteria are the dominant bacteria in vineyard soils. Moreover, it is interesting that the 31 clone sequences assigned to Actinobacteria were suddenly found in soils sampled from October 2008 to December 2008. Dell'Amico et al ${ }^{21}$ described that a specific microbe in copper-contaminated soil may serve as an indicator of soil pollution status. Meanwhile, Actinobacteria are prevalent in copper-contaminated nonamended soil. ${ }^{22}$ Smit et al ${ }^{45}$ suggested that the ratio of the number of Proteobacteria to that of Acidobacteria may be an indicator of the nutritional status of soils. Therefore, the soils sampled from October 2008 to December 2008 might be organic-matter rich. However, because we assessed only the contents of copper and organic matter in vineyard soils, we could not determine whether the microbial community in the soils was a result of the effects of copper and organic matter. At the very least, we can say that there was no organic amendment before the appearance of Actinobacteria in any of the vineyard soils tested.

We were able to detect some species, including phytopathogenic and/or valuable fungi, and to observe the current status of vineyard soils. Although our sequence data are not sufficient to confirm the microbial community in Japanese vineyard soils, we preliminarily generated a microbial catalog that records the physical, chemical, and biologic properties of Japanese vineyard soils and their implications for viticulture (Supplementary Tables 1 and 2). This catalog may help further our understanding of the current state of vineyard soils and promote the management, maintenance, and improvement of vineyards. Although vineyard soil properties are complex, we may be able to elucidate gradually the characteristics of vineyard soils by using a PCR-culture-independent approach and generating a microbial catalog.

\section{Conclusion}

We demonstrated for the first time the community structures of fungi and bacteria in Japanese vineyard soils by a PCRculture-independent approach and generated a microbial catalog. Our results suggest that many fungal and bacterial species exist in vineyard soils and the microbial community structure in each vineyard soil sample is extremely diverse. Moreover, the dominant fungal and bacterial groups are dissimilar to the dominant microbes in forest and agricultural soils. We were not able to determine the dominant microbes at the species level due to the limited sample size. By analyzing microbes on a large scale, vineyard soil characteristics will be revealed in detail and soil condition assessment using microbial community structures will be realized.

\section{Acknowledgment}

This work was supported by the Sasakawa Scientific Research Grant from The Japan Science Society.

\section{Disclosure}

The authors report no conflict of interest in this work.

\section{References}

1. Garbeva P, van Veen JA, van Elsas JD. Microbial diversity in soil: Selection of microbial populations by plant and soil type and implications for disease suppressiveness. Anпи Rev Phytopathol. 2004;42:243-270.

2. Kennedy AC, Smith KL. Soil microbial diversity and the sustainability of agricultural soils. Plant Soil. 1995;170:75-86.

3. Torsvik V, Øvreås L. Microbial diversity and function in soil: From genes to ecosystems. Curr Opin Microbiol. 2002;5:240-245.

4. Garland JL. Analytical approaches to the characterization of samples of microbial communities using patterns of potential C utilization. Soil Biol Biochem. 1996;28:213-221.

5. Süß J, Engelen B, Cypionka H, Sass H. Quantitative analysis of bacterial communities from Mediterranean sapropels based on cultivationdependent methods. FEMS Microbiol Ecol. 2004;51:109-121.

6. Hoshino YT, Hasebe R. DNA extraction from soil. J Environ Biotechnol. 2005;5:43-53.

7. Anderson IC, Campbell CD, Prosser JI. Potential bias of fungal $18 \mathrm{~S}$ rDNA and internal transcribed spacer polymerase chain reaction primers for estimating fungal biodiversity in soil. Environ Microbiol. 2003;5:36-47

8. Gelsomino A, Keijzer-Wolters AC, Cacco G, van Elsas JD. Assessment of bacterial community structure in soil by polymerase chain reaction and denaturing gradient gel electrophoresis. J Microbiol Methods. 1999;38:1-15.

9. Anderson IC, Campbell CD. Diversity and ecology of soil fungal communities: increased understanding through the application of molecular technique. Environ Microbiol. 2004;6:769-779.

10. Anderson IC, Parkin PI, Campbell CD. DNA- and RNA-derived assessments of fungal community composition in soil amended with sewage sludge rich in cadmium, copper and zinc. Soil Biol Biochem. 2008;40: 2358-2365.

11. Sessitsch A, Weilharter A, Gerzabek MH, Kirchmann H, Kandeler E. Microbial population structures in soil particle size fractions of a longterm fertilizer field experiment. Appl Environ Microbiol. 2001;67: $4215-4224$. 
12. Marschner P, Yang CH, Lieberei R, Crowley DE. Soil and plant specific effects on bacterial community composition in the rhizosphere. Soil Biol Biochem. 2001;33:1437-1445.

13. Kennedy NM, Gleeson DE, Connolly J, Clipson NJW. Seasonal and management influences on bacterial community structure in an upland grassland soil. FEMS Microbiol Ecol. 2005;53:329-337.

14. Lipson DA, Schmidt SK. Seasonal changes in an alpine soil bacterial community in the Colorado Rocky Mountains. Appl Environ Microbiol. 2004;70:2867-2879.

15. Hartmann M, Widmer F. Community structure analyses are more sensitive to difference in soil bacterial communities than anonymous diversity indices. Appl Environ Microbiol. 2006;72:7804-7812.

16. Upchurch R, Chiu CY, Everett K, Dyszynski G, Coleman DC, Whitman WB. Differences in the composition and diversity of bacterial communities form agricultural and forest soils. Soil Biol Biochem. 2008;40:1294-1305.

17. White RE. Soil for Fine Wine. New York, NY: Oxford University Press; 2003.

18. White RE. Understanding Vineyard Soils. New York, NY: Oxford University Press; 2009.

19. Steenwerth KL, Drenovsky RE, Lambert JJ, Kluepfel DA, Scow KM, Smart DR. Soil morphology, depth and grapevine root frequency influence microbial communities in a pinot noir vineyard. Soil Biol Biochem. 2008;40:1330-1340.

20. Saison C, Degrange V, Oliver R, et al. Alteration and resilience of the soil microbial community following compost amendment: Effects of compost level and compost-borne microbial community. Environ Microbiol. 2006;8:247-257.

21. Dell'Amico E, Mazzocchi M, Cavalca L, Allievi L, Andreoni V. Assessment of bacterial community structure in a long-term copperpolluted ex-vineyard soil. Microbiol Res. 2008;163:671-683.

22. Lejon DPH, Martins JMF, Lévêque J, et al. Copper dynamic and impact on microbial communities in soils of variable organic status. Environ Sci Technol. 2008;42:2819-2825.

23. CMG GardenNotes [Homepage on the Internet]. Colorado: Colorado State University Extension; c2007. Available from: http://cmg.colostate. edu/gardennotes/214.pdf. Accessed Jun 20, 2010.

24. Basic Local Alignment Search Tool [Homepage on the internet]. National Center for Biotechnology Information. Available from: http:// blast.ncbi.nlm.nih.gov/Blast.cgi. Accessed Feb, 2010.

25. Tamura K, Dudley J, Nei M, Kumar S. MEGA4: Molecular Evolutionary Genetics Analysis (MEGA) software version 4.0. Mol Biol Evol. 2007;24:1596-1599. Available from: www.megasoftware.net

26. Wang Q, Garrity GM, Tiedje JM, Cole JR. Naïve Bayesian Classifier for rapid assignment of rRNA sequences into the new bacterial taxonomy. Appl Environ Microbiol. 2007;73:5261-5267.

27. Oehl F, Sieverding E, Ineichen K, Ris EA, Boller T, Wiemken A. Community structure of arbuscular mycorrhizal fungi at different soil depths in extensively and intensively managed agroecosystems. New Phytol. 2005;165:273-283.
28. Schreiner RP, Mihara KL. The diversity of arbuscular mycorrhizal fungi amplified from grapevine roots (Vitis vinifera L.) in Oregon vineyards is seasonally stable and influenced by soil and vine age. Mycologia. 2009;101:599-611.

29. Whitelaw-Weckert MA, Rahman L, Hutton RJ, Coombes N. Permanent swards increase soil microbial counts in two Australian vineyards. Appl Soil Ecol. 2007;36:224-232.

30. O’Brien HE, Parrent JL, Jackson JA, Moncalvo JM, Vilgalys R. Fungal community analysis by large-scale sequencing of environmental samples. Appl Environ Microbiol. 2005;71:5544-5550.

31. Lim YW, Kim BK, Kim C, et al. Assessment of soil fungal communities using pyrosequencing. J Microbiol. 2010;48:284-289.

32. Michielse CB, Rep M. Pathogen profile update: Fusarium oxysporum. Mol Plant Pathol. 2009;10:311-324.

33. van Niekerk JM, Groenewald JZ, Farr DF, Fourie PH, Halleen F, Crous PW. Reassessment of Phomopsis species on grapevines. Austral Plant Pathol. 2005;34:27-39.

34. Leong SL, Hocking AD, Scott ES. Aspergillus species producing ochratoxin A: Isolation from vineyard soils and infection of Semillon bunches in Australia. J Appl Microbiol. 2007;102:124-133.

35. Perrone G, Susca A, Cozzi G, et al. Biodiversity of Aspergillus species in some important agricultural products. Stud Mycol. 2007;59:53-66.

36. Blanchette RA, Held BW, Arenz BE, et al. An Antarctic hot spot for fungi at Shackleton's historic hut on Cape Royds. Microb Ecol. In press 2010.

37. Mäder P, Fliessbach A, Dubois D, Gunst L, Fried P, Niggli U. Soil fertility and biodiversity in organic farming. Science. 2002;296:1694-1697.

38. Fierer N, Jackson RB. The diversity and biogeography of soil bacterial communities. Proc Natl Acad Sci U S A. 2006;103: 626-631.

39. Bates ST, Garcia-Pichel F. A culture-independent study of free-living fungi in biological soil crusts of the Colorado Plateau: Their diversity and relative contribution to microbial biomass. Environ Microbiol. 2009;11:56-67.

40. White RE. The living soil. In: Understanding Vineyard Soils. New York, NY: Oxford University Press; 2009.

41. Rappé MS, Giovannoni SJ. The uncultured microbial majority. Annu Rev Microbiol. 2003;57:369-394.

42. Roesch LF, Fulthorpe RR, Riva A, et al. Pyrosequencing enumerates and contrasts soil microbial diversity. ISME J. 2007;1:283-290.

43. Acosta-Martínez V, Dowd S, Sun Y, Allen V. Tag-encoded pyrosequencing analysis of bacterial diversity in a single soil type as affected by management and land use. Soil Biol Biochem. 2008;40:2762-2770.

44. Buée M, Reich M, Murat C, et al. 454 Pyrosequencing analyses of forest soils reveal an unexpectedly high fungal diversity. New Phytol. 2009; 184:449-456.

45. Smit E, Leeflang P, Gommans S, van den Broek J, van Mil S, Wernars K. Diversity and seasonal fluctuations of the dominant members of bacterial soil community in a wheat field as determined by cultivation and molecular methods. Appl Environ Microbiol. 2001;67:2284-2291. 


\section{Supplementary tables}

Table SI Catalog of fungi with the highest sequence similarity to clones by BLAST search and distribution of clones in each library

\begin{tabular}{|c|c|c|c|c|c|c|c|c|c|c|c|c|c|c|c|}
\hline \multirow[t]{2}{*}{ Phylum } & \multirow{2}{*}{$\begin{array}{l}\text { Blast match/clone } \\
\text { name }\end{array}$} & \multirow{2}{*}{$\begin{array}{l}\text { Accession } \\
\text { number }\end{array}$} & \multirow{2}{*}{$\begin{array}{l}\text { ITS } \\
\text { size } \\
\text { (bp) }\end{array}$} & \multirow{2}{*}{$\begin{array}{l}\text { Identity } \\
\text { (\%) }\end{array}$} & \multicolumn{10}{|c|}{ Number of fungal ITS clones } & \\
\hline & & & & & KI & K2 & $\mathbf{K} 3$ & K4 & A & B & C & $\mathbf{D}$ & $\mathbf{E}$ & $\mathbf{F}$ & $\mathbf{G}$ \\
\hline Ascomycota & $\begin{array}{l}\text { Alternaria } \\
\text { tenuissima }\end{array}$ & FJ766500 & 220 & 100 & & & & & & & 3 & & & & $\mathrm{I}$ \\
\hline 58 OTUs & Arthopyreniaceae sp & FJ439584 & 220 & 98 & & & & & & & & & 1 & & \\
\hline \multirow[t]{40}{*}{210 clones } & Ascochyta sp & FJ032642 & 195 & 100 & 1 & & I & & & & & & & & \\
\hline & Aspergillus & GQ3594I3 & 232 & $100-99$ & & & & & & & 6 & & & I & \\
\hline & japonicus & & & & & & & & & & & & & & \\
\hline & $\begin{array}{l}\text { Aspergillus } \\
\text { versicolor }\end{array}$ & GU232767 & 211 & $100-99$ & & & & & & & 7 & & & & \\
\hline & $\begin{array}{l}\text { Aureobasidium } \\
\text { pullulans }\end{array}$ & GU062250 & 235 & $100-99$ & 2 & & & 1 & & & 6 & & & & \\
\hline & Chaetomium sp & EU75069I & 221 & 100 & & & & & & & & & & I & \\
\hline & $\begin{array}{l}\text { Cladophialophora } \\
\text { chaetospira }\end{array}$ & EU035406 & 247 & 100 & & & & & & & & I & & & \\
\hline & $\begin{array}{l}\text { Cladorrhinum } \\
\text { samala }\end{array}$ & FM955447 & 224 & 90 & & & & & & & & 2 & & & 3 \\
\hline & $\begin{array}{l}\text { Cladorrhinum } \\
\text { samala }\end{array}$ & FM955447 & 227 & 97 & & & & & & I & & & & & \\
\hline & Cordyceps & AJ309335 & 224 & 95 & & & & 1 & & & & & & & \\
\hline & robertsii & & & & & & & & & & & & & & \\
\hline & Corynascus & FJ537093 & 220 & 93 & & & & & & & & I & & & \\
\hline & verrucosus & & & & & & & & & & & & & & \\
\hline & $\begin{array}{l}\text { Cylindrocarpon } \\
\text { didymum }\end{array}$ & GU067762 & 191 & 100 & & & & & & & & & & & I \\
\hline & Cylindrocarpon & DQ178166 & 193 & 100 & & & & & & & & $\mathrm{I}$ & & & \\
\hline & liriodendri & & & & & & & & & & & & & & \\
\hline & Discosia sp & AF405303 & 243 & 95 & & & & & & 1 & & & & & \\
\hline & Doratomyces & FJ9I4706 & 229 & 99 & & & & & & & & & & & 2 \\
\hline & nanus & & & & & & & & & & & & & & \\
\hline & $\begin{array}{l}\text { Exophiala } \\
\text { pisciphila }\end{array}$ & DQ826739 & 251 & 100 & 1 & & & & & & & & & & \\
\hline & $\begin{array}{l}\text { Fusarium } \\
\text { avenaceum }\end{array}$ & GU454800 & 206 & 99 & & & & & 1 & & & & & & \\
\hline & $\begin{array}{l}\text { Fusarium } \\
\text { oxysporum }\end{array}$ & GU445380 & 203 & $100-99$ & & & & & & & 6 & & & & I \\
\hline & Fusarium solani & AB5I385I & 205 & $100-99$ & & I & 1 & & & & & & & & \\
\hline & f. radicicola & & & & & & & & & & & & & & \\
\hline & Fusarium sp & EU86007I & 207 & 88 & 1 & & & & & & & & & & \\
\hline & Fusarium sp & GQ505759 & 203 & 99 & & 1 & & & & & & & & & \\
\hline & Fusarium sp & GQ50576I & 204 & $100-99$ & & & & & 1 & 1 & & & & & I \\
\hline & $\begin{array}{l}\text { Hirsutella } \\
\text { minnesotensis }\end{array}$ & DQ345572 & 230 & 99 & & & & & 1 & & & & & & \\
\hline & Lecythophora sp & GU062252 & 228 & 97 & & & & & & & & I & & & \\
\hline & $\begin{array}{l}\text { Leptodontidium } \\
\text { orchidicola }\end{array}$ & GQ302678 & 290 & $100-99$ & & & & 2 & & & & & & & \\
\hline & Leptosphaerulina sp & EF694653 & 269 & 100 & 1 & & & & & & & & & & \\
\hline & Microscypha ellisii & U57493 & 216 & $98-96$ & & & & & & & I & 24 & & & 2 \\
\hline & Nectria & FJ940904 & 208 & 99 & & & & & & & & & & & I \\
\hline & mariannaeae & & & & & & & & & & & & & & \\
\hline & Nectria sp. & GU067752 & 208 & 99 & 1 & & & & & & & & 1 & & \\
\hline & Onygenales sp & GU2I 2408 & 234 & 97 & & & & & & & & & 2 & & \\
\hline & Penicillium sp & AB468053 & 228 & 100 & & & I & & & & & & & & \\
\hline & Penicillium sp & GU270577 & 195 & 100 & & & & & I & & & & & & \\
\hline & Pezizomycotina sp & GU2I 2420 & 227 & $99-98$ & & & & & 21 & & & & 3 & & 2 \\
\hline & Phialocephala fluminis & AF486I24 & 260 & 86 & 1 & & & & & & & & & & \\
\hline
\end{tabular}


Table SI (Continued)

\begin{tabular}{|c|c|c|c|c|c|c|c|c|c|c|c|c|c|c|c|}
\hline \multirow[t]{2}{*}{ Phylum } & \multirow{2}{*}{$\begin{array}{l}\text { Blast match/clone } \\
\text { name }\end{array}$} & \multirow{2}{*}{$\begin{array}{l}\text { Accession } \\
\text { number }\end{array}$} & \multirow{2}{*}{$\begin{array}{l}\text { ITS } \\
\text { size } \\
\text { (bp) }\end{array}$} & \multirow{2}{*}{$\begin{array}{l}\text { Identity } \\
\text { (\%) }\end{array}$} & \multicolumn{11}{|c|}{ Number of fungal ITS clones } \\
\hline & & & & & $\mathbf{K I}$ & K2 & K3 & K4 & A & B & C & D & $\mathbf{E}$ & $\mathbf{F}$ & G \\
\hline & Phomopsis sp & GU462I50 & 230 & $100-99$ & & & & & & & 10 & & & & \\
\hline & Phomopsis sp & GU462I49 & 232 & 98 & & & & & & & 10 & & & & \\
\hline & Pilidiella sp & GU0623I7 & 261 & 98 & I & & & & & I & & & & & \\
\hline & $\begin{array}{l}\text { Plectosphaerella } \\
\text { cucumerina }\end{array}$ & GU062300 & 194 & 100 & I & & 2 & & & & & & & & \\
\hline & Podospora didyma & AY999I27 & 210 & 89 & & & & & & & & 6 & & & \\
\hline & $\begin{array}{l}\text { Pseudaleuria } \\
\text { quinaultiana }\end{array}$ & EU669387 & 252 & $86-85$ & & & & & & 2 & & & I & & \\
\hline & Sordariomycete sp & EF69465I & 197 & 99 & & & & & & $\mathrm{I}$ & & & & & \\
\hline & Stilbella sp & DQ993633 & 209 & 98 & & & & & & & & & & 2 & \\
\hline & $\begin{array}{l}\text { Trichoderma } \\
\text { hamatum }\end{array}$ & GQ331987 & 238 & $100-98$ & & & & I & & & & 1 & 2 & & 2 \\
\hline & Uncultured & EF619630 & 244 & 99 & & & & & & I & & & & & \\
\hline & Amphisphaeriaceae & & & & & & & & & & & & & & \\
\hline & Uncultured & AM90I745 & 248 & 100 & & & & I & & & & & & & \\
\hline & Ascomycete & & & & & & & & & & & & & & \\
\hline & Uncultured & AM901946 & 202 & 99 & & & & I & & & & & & & \\
\hline & Ascomycete & & & & & & & & & & & & & & \\
\hline & Uncultured & EU003078 & 228 & 98 & & & 3 & & & & & & & & \\
\hline & Ascomycete & & & & & & & & & & & & & & \\
\hline & Uncultured & EU490130 & 229 & $100-99$ & I & 3 & & 3 & & & & & & & \\
\hline & Ascomycete & & & & & & & & & & & & & & \\
\hline & Uncultured & EU520620 & 202 & $98-97$ & I & & & & & & & & 2 & & \\
\hline & Ascomycota & & & & & & & & & & & & & & \\
\hline & Uncultured & FJ440864 & 228 & 100 & & & & & & & & 1 & & & \\
\hline & Ascomycota & & & & & & & & & & & & & & \\
\hline & Uncultured & GQ223459 & 244 & 98 & I & & & & & & & & & & \\
\hline & Geopyxis & & & & & & & & & & & & & & \\
\hline & Uncultured & GU055674 & 199 & $93-92$ & & & & & & 5 & & & & & \\
\hline & Lasiosphaeriaceae & & & & & & & & & & & & & & \\
\hline & Uncultured & GU055705 & 216 & 85 & & & & & & & & & I & & \\
\hline & Tetracladium & & & & & & & & & & & & & & \\
\hline & Uncultured & GU055705 & 216 & $100-99$ & I & & & & 3 & & & & 9 & & \\
\hline & Tetracladium & & & & & & & & & & & & & & \\
\hline & Uncultured & GU056018 & 198 & 99 & & I & & & & & & & & & \\
\hline & Xylariales & & & & & & & & & & & & & & \\
\hline & Verticillium & AJ2924I3 & 231 & 98 & & & & & & I & & & & & \\
\hline & balanoides & & & & & & & & & & & & & & \\
\hline & $\begin{array}{l}\text { Wardomyces } \\
\text { inflatus }\end{array}$ & FJ946485 & 227 & 99 & & & & & & & & & & & I \\
\hline Basidiomycota & Aqaricus romaqnesii & FJ478II8 & 346 & 99 & 3 & & & & & & & & & & \\
\hline 15 OTUs & Ceratobasidium sp & FJ435I47 & 234 & $100-99$ & & & & 4 & & & & & & & \\
\hline 57 clones & Conocybe rickenii & AYI9454I & 318 & 81 & 2 & & & & & & & & & & \\
\hline & Cryptococcus sp & FJ210546 & 193 & $100-99$ & 2 & & & & & & & & & & \\
\hline & Mallorcan & AF438588 & 338 & 89 & & & & & & & & 2 & & & \\
\hline & basidiomycete & & & & & & & & & & & & & & \\
\hline & Mycorrhiza of & AY052375 & 240 & 83 & & & & I & & & & & & & \\
\hline & $\begin{array}{l}\text { Neottia Nidus-avis } \\
\text { (Sebacinaceae) spp }\end{array}$ & & & & & & & & & & & & & & \\
\hline & Nematoctonus & EF409766 & 310 & 90 & & I & & & & & & & & & \\
\hline & tylosporus & & & & & & & & & & & & & & \\
\hline & Phlebia livida & AB084618 & 238 & 89 & & & & I & & & & & & & \\
\hline & Phlebia sp & AY787680 & 256 & 92 & & 2 & & & & & & & & & \\
\hline & Uncultured & FJ554256 & 220 & 95 & & & & & & & & & & & I \\
\hline & Agaricomycetes & & & & & & & & & & & & & & \\
\hline
\end{tabular}

(Continued) 
Table SI (Continued)

\begin{tabular}{|c|c|c|c|c|c|c|c|c|c|c|c|c|c|c|c|}
\hline \multirow[t]{2}{*}{ Phylum } & \multirow{2}{*}{$\begin{array}{l}\text { Blast match/clone } \\
\text { name }\end{array}$} & \multirow{2}{*}{$\begin{array}{l}\text { Accession } \\
\text { number }\end{array}$} & \multirow{2}{*}{$\begin{array}{l}\text { ITS } \\
\text { size } \\
\text { (bp) }\end{array}$} & \multirow{2}{*}{$\begin{array}{l}\text { Identity } \\
(\%)\end{array}$} & \multicolumn{11}{|c|}{ Number of fungal ITS clones } \\
\hline & & & & & $\mathbf{K} \mathbf{I}$ & $\mathbf{K 2}$ & $\mathbf{K} 3$ & K4 & A & B & C & D & $\mathbf{E}$ & $\mathbf{F}$ & G \\
\hline & Uncultured & AM90I82I & 162 & 100 & & & & & & & & & & & 1 \\
\hline & Basidiomycete & & & & & & & & & & & & & & \\
\hline & Uncultured & AY970109 & 240 & 99 & I & & I & 7 & & & & & & & \\
\hline & Basidiomycete & & & & & & & & & & & & & & \\
\hline & Uncultured & DQ182419 & 231 & $96-95$ & & 3 & 2 & 7 & & & & & & & \\
\hline & Ceratobasidiaceae & & & & & & & & & & & & & & \\
\hline & Uncultured soil & DQ672332 & 219 & $99-95$ & & $\mathrm{I}$ & & I & & & & & & & \\
\hline & Basidiomycete & & & & & & & & & & & & & & \\
\hline & Uncultured & EU030400 & 206 & 99 & & & & & 2 & & & & 2 & & 9 \\
\hline & Tremellomycete & & & & & & & & & & & & & & \\
\hline Zygomycota & Endogone lactiflua & AY997045 & 241 & 82 & & & I & & & & & & & & \\
\hline \multirow[t]{2}{*}{6 OTUs } & Uncultured & FJ553286 & 202 & $100-99$ & 2 & & I & & & & & & & & \\
\hline & Mortierella & & & & & & & & & & & & & & \\
\hline \multirow[t]{8}{*}{34 clones } & Uncultured & FJ4409I4 & 203 & $88-87$ & & & & & 4 & & & & & 7 & 2 \\
\hline & Mortierellales & & & & & & & & & & & & & & \\
\hline & Uncultured & EF027378 & 248 & $95-94$ & & & & & & 2 & & & & & \\
\hline & Zygomycete & & & & & & & & & & & & & & \\
\hline & Uncultured & EU490044 & 213 & $85-84$ & 4 & 8 & & & & & & & & & \\
\hline & Zygomycete & & & & & & & & & & & & & & \\
\hline & Uncultured & FN295478 & 196 & 99 & & & & & & & & & & 3 & \\
\hline & Zygomycete & & & & & & & & & & & & & & \\
\hline Glomeromycota & Glomus irregulare & FJ009618 & 162 & 99 & I & I & & I & & & & & & & \\
\hline II OTUs & Glomus sp & AYI74689 & 164 & 95 & & & I & & & & & & & & \\
\hline \multirow[t]{9}{*}{16 clones } & Glomus sp & FM865557 & 162 & 99 & & I & & & & & & & & & \\
\hline & Glomus versiforme & AJ5I6931 & 158 & 98 & & & & & & & & 1 & & & \\
\hline & Uncultured Glomus & AM494593 & 174 & 97 & & & & I & & & & & & & \\
\hline & Uncultured Glomus & AM495I89 & 170 & 97 & & & & I & & & & & & & \\
\hline & Uncultured Glomus & AM99282I & 162 & 100 & & I & & & & & & & & & \\
\hline & Uncultured Glomus & AY236284 & 167 & $95-94$ & & & I & I & & & & & & & \\
\hline & Uncultured Glomus & AY236285 & 168 & 94 & & & & I & & & & & & & \\
\hline & Uncultured Glomus & EU93। 248 & 162 & 93 & & & & I & & & & & & & \\
\hline & Uncultured Glomus & FJ769323 & 162 & 98 & & & & & & I & & & 2 & & \\
\hline Oomycetes & $\begin{array}{l}\text { Pythium } \\
\text { chamaehyphon }\end{array}$ & AJ233440 & 297 & 97 & & & I & & & & & & & & \\
\hline 3 OTUs & $\begin{array}{l}\text { Pythium } \\
\text { rostratifingens }\end{array}$ & GQ160433 & 358 & 99 & & & & & & & & & & 1 & \\
\hline 21 clones & Pythium sylvaticum & DQ52874I & 346 & $100-99$ & 4 & 5 & 2 & 2 & & & & & 4 & & 2 \\
\hline Unclassified & $\begin{array}{l}\text { Environmental } \\
\text { fungal }\end{array}$ & AMII 3724 & 204 & $95-94$ & & & & 2 & & & & & & 1 & \\
\hline 96 OTUs & Fungal endophyte sp & FJ025263 & 227 & 97 & & & & I & & & & & & & \\
\hline \multirow[t]{9}{*}{260 clones } & Fungal sp & FJ6I288I & 225 & 96 & & & & & & & & I & & & \\
\hline & Fungal sp & FJ2360II & 226 & 99 & & & & & 1 & & & & & & \\
\hline & Soil fungal sp & EU076954 & 218 & 95 & & & & & & & & 3 & & & \\
\hline & $\begin{array}{l}\text { Uncultured } \\
\text { endophytic fungus }\end{array}$ & EF505576 & 225 & 100 & & & & & 1 & & & & & & \\
\hline & $\begin{array}{l}\text { Uncultured } \\
\text { endophytic fungus }\end{array}$ & FJ524320 & 289 & 91 & I & & & & & & & & & & \\
\hline & $\begin{array}{l}\text { Uncultured } \\
\text { endophytic fungus }\end{array}$ & FJ882010 & 206 & 95 & & & & & & 3 & & & & & \\
\hline & Uncultured fungus & AY6I5930 & 264 & 99 & & & & 1 & & & & & & & \\
\hline & Uncultured fungus & AY970243 & 172 & 100 & & & & & & & & & & 1 & \\
\hline & Uncultured fungus & DQ294949 & 206 & 89 & & & & & & & & & & I & \\
\hline
\end{tabular}


Table SI (Continued)

\begin{tabular}{|c|c|c|c|c|c|c|c|c|c|c|c|c|c|c|c|}
\hline \multirow[t]{2}{*}{ Phylum } & \multirow{2}{*}{$\begin{array}{l}\text { Blast match/clone } \\
\text { name }\end{array}$} & \multirow{2}{*}{$\begin{array}{l}\text { Accession } \\
\text { number }\end{array}$} & \multirow{2}{*}{$\begin{array}{l}\text { ITS } \\
\text { size } \\
\text { (bp) }\end{array}$} & \multirow{2}{*}{$\begin{array}{l}\text { Identity } \\
(\%)\end{array}$} & \multicolumn{11}{|c|}{ Number of fungal ITS clones } \\
\hline & & & & & $\mathbf{K} \mathbf{I}$ & K2 & $\mathbf{K} 3$ & K4 & $\mathbf{A}$ & B & C & D & $\mathbf{E}$ & $\mathbf{F}$ & G \\
\hline & Uncultured fungus & EF434103 & 217 & 94 & & & & & & & & & & & I \\
\hline & Uncultured fungus & EF521250 & 234 & 82 & 1 & & & & & & & & 1 & & \\
\hline & Uncultured fungus & EU096296 & 319 & 81 & & 2 & & & & & & & & & \\
\hline & Uncultured fungus & EU0963II & 256 & 93 & & & & & & & & & & & I \\
\hline & Uncultured fungus & EU292672 & 234 & 82 & & & & & & & & 2 & & & \\
\hline & Uncultured fungus & EU437428 & 201 & $100-99$ & & & & & & 17 & & & 1 & & \\
\hline & Uncultured fungus & EU437434 & 205 & 99 & & & & & I & & & & & & \\
\hline & Uncultured fungus & EU516926 & 398 & 98 & & & & & & & & & & & I \\
\hline & Uncultured fungus & $\mathrm{FJ} 213503$ & 246 & 99 & I & I & & & & & & & & & \\
\hline & Uncultured fungus & FJ386909 & 229 & 99 & & & & & & & & 1 & & & \\
\hline & Uncultured fungus & FJ758408 & 208 & 100 & I & & & & & & & & & & \\
\hline & Uncultured fungus & FJ76II 34 & 189 & 99 & & & I & & & & & & & & \\
\hline & Uncultured fungus & FJ776046 & 192 & 96 & 2 & & & 2 & & & & & & & \\
\hline & Uncultured fungus & FJ776073 & 202 & 100 & & & & & 9 & & & & & I & I \\
\hline & Uncultured fungus & FJ776292 & 211 & 100 & & & 2 & & & 3 & & & & & \\
\hline & Uncultured fungus & FJ7764I5 & 216 & 99 & & I & & & & & & & & & \\
\hline & Uncultured fungus & FJ776569 & 260 & $98-96$ & & & I & I & & & & & & & \\
\hline & Uncultured fungus & FJ7768I3 & 209 & 99 & I & & & & & & & & & & \\
\hline & Uncultured fungus & FJ777I 83 & 208 & 100 & & & & & & & & & & & 3 \\
\hline & Uncultured fungus & FJ777429 & 258 & 97 & I & & & & & & & & & & \\
\hline & Uncultured fungus & FJ777950 & 247 & 99 & I & & & & & & & & & & \\
\hline & Uncultured fungus & FJ77807I & 234 & 100 & & & & & 1 & & & & & & \\
\hline & Uncultured fungus & FJ778090 & 218 & 98 & & & & & I & & & & & & \\
\hline & Uncultured fungus & FJ778326 & 220 & 94 & I & & & & & & & & & & \\
\hline & Uncultured fungus & FJ778637 & 261 & 86 & & 3 & & & & & & & & & \\
\hline & Uncultured fungus & FJ779194 & 200 & 100 & & & & & & & & & & 2 & \\
\hline & Uncultured fungus & FJ779858 & 215 & 100 & & & & & & I & & & & & \\
\hline & Uncultured fungus & FJ780520 & 200 & 94 & & & & & & & 2 & & & & \\
\hline & Uncultured fungus & FJ780554 & 246 & 93 & & 1 & & & & & & & & & \\
\hline & Uncultured fungus & FJ780875 & 218 & 98 & & & & & & & & & & I & \\
\hline & Uncultured fungus & FJ780914 & 217 & $98-95$ & & I & I & & & & & & 1 & & \\
\hline & Uncultured fungus & FJ781005 & 156 & $96-95$ & & & & 3 & & & & & 1 & & \\
\hline & Uncultured fungus & Fj781013 & 224 & $93-91$ & & & I & I & & & & & & & \\
\hline & Uncultured fungus & FJ78I42I & 245 & 97 & & & & 5 & & & & & & & \\
\hline & Uncultured fungus & FJ78I525 & 249 & 87 & & I & & & & & & & & & \\
\hline & Uncultured fungus & FJ782853 & 208 & $99-97$ & I & & I & & & & & & & & \\
\hline & Uncultured fungus & FJ783024 & 189 & 97 & & & & & & & & & & & I \\
\hline & Uncultured fungus & FJ783279 & 222 & 100 & & & & & 1 & & & & & & \\
\hline & Uncultured fungus & FJ857928 & 212 & $100-99$ & I & & I & 2 & & & & & & & \\
\hline & Uncultured fungus & FM999592 & 226 & 93 & & & & & & & & & & I & \\
\hline & Uncultured fungus & FN397288 & 238 & 95 & & & & & & & 2 & & & & \\
\hline & Uncultured fungus & FN397382 & 214 & 100 & I & & & & & & & & & & \\
\hline & Uncultured fungus & FN397399 & 233 & 98 & & & & & & I & & & & & \\
\hline & Uncultured fungus & FN39742I & 198 & 99 & & & & I & & & & & & & \\
\hline & Uncultured fungus & GQ225II7 & 244 & $100-99$ & & & & & & & & & & & 5 \\
\hline & Uncultured fungus & GQ225I49 & 205 & 99 & & & & & & & & & 1 & & \\
\hline & Uncultured fungus & GQ225160 & 201 & $100-99$ & & & & & & 4 & & & & 2 & \\
\hline & Uncultured fungus & GQ50852I & 211 & 100 & & & & & & I & & & & & \\
\hline & Uncultured fungus & GQ50933I & 211 & 100 & & I & & & & & & & & & \\
\hline & Uncultured fungus & GQ509370 & 211 & 100 & & & & & & I & & & & & \\
\hline & Uncultured fungus & GQ509504 & 211 & 100 & & & & & & I & & & & & \\
\hline & Uncultured fungus & GQ509519 & 211 & 100 & I & & & & & & & & & & \\
\hline & Uncultured fungus & GQ510910 & 211 & 100 & I & & & & & & & & & & \\
\hline & Uncultured fungus & GQ5III89 & 198 & 100 & & & I & & & & & & & & \\
\hline & Uncultured fungus & GQ5II388 & 211 & 100 & & I & & & & & & & & & \\
\hline & Uncultured fungus & GQ5I3703 & 262 & 90 & & & & & & & & & 1 & & \\
\hline & Uncultured fungus & GQ5I5874 & 211 & 100 & & I & & & & & & & & & \\
\hline & Uncultured fungus & GQ5I7307 & 220 & 100 & & & & & & & & $\mathrm{I}$ & & & \\
\hline
\end{tabular}

(Continued) 
Table SI (Continued)

\begin{tabular}{|c|c|c|c|c|c|c|c|c|c|c|c|c|c|c|c|}
\hline \multirow[t]{2}{*}{ Phylum } & \multirow{2}{*}{$\begin{array}{l}\text { Blast match/clone } \\
\text { name }\end{array}$} & \multirow{2}{*}{$\begin{array}{l}\text { Accession } \\
\text { number }\end{array}$} & \multirow{2}{*}{$\begin{array}{l}\text { ITS } \\
\text { size } \\
\text { (bp) }\end{array}$} & \multirow{2}{*}{$\begin{array}{l}\text { Identity } \\
(\%)\end{array}$} & \multicolumn{11}{|c|}{ Number of fungal ITS clones } \\
\hline & & & & & $\mathbf{K} \mathbf{I}$ & $\mathbf{K 2}$ & K3 & K4 & A & B & C & D & $\mathbf{E}$ & $\mathbf{F}$ & G \\
\hline & Uncultured fungus & GQ523707 & 211 & 100 & & 1 & & & & & & & & & \\
\hline & Uncultured fungus & GQ866I83 & 222 & 99 & & & & & & 1 & & & & & \\
\hline & Uncultured fungus & GQ866184 & 193 & 98 & & & & & & & & I & & & \\
\hline & Uncultured fungus & GQ866220 & 220 & $100-98$ & 4 & 6 & & & I & 1 & & & & I & 3 \\
\hline & Uncultured fungus & GU078626 & 217 & $100-99$ & & & & & I & $\mathrm{I}$ & & I & 1 & 6 & 1 \\
\hline & Uncultured fungus & GU078639 & 222 & 99 & & 1 & & & & & & & & & \\
\hline & Uncultured fungus & GU256955 & 195 & 100 & & & & & I & & & & & & \\
\hline & Uncultured fungus & GU366724 & 219 & 100 & I & 1 & & & & & & & & I & I \\
\hline & Uncultured fungus & GU370749 & 211 & $100-99$ & 8 & 17 & I & 1 & & 4 & & & & & \\
\hline & Uncultured fungus & GU46I346 & 198 & 100 & & & & & & & & & & I & \\
\hline & Uncultured fungus & GU461399 & 198 & 100 & & & & & & & & & & 4 & \\
\hline & Uncultured fungus & GU46|434 & 216 & $100-98$ & & & & & & & & 3 & & I & \\
\hline & Uncultured fungus & GU46I440 & 234 & 100 & & & & & & & & & & 1 & \\
\hline & Uncultured fungus & GU46I574 & 201 & $100-99$ & & & & & & & & & & & 2 \\
\hline & Uncultured & AB4544II & 237 & $100-99$ & 4 & 2 & I & 3 & & & & & & & \\
\hline & mycorrhizal fungus & & & & & & & & & & & & & & \\
\hline & $\begin{array}{l}\text { Uncultured soil } \\
\text { fungus }\end{array}$ & DQ420769 & 248 & $90-89$ & I & & I & & & & & & 1 & & \\
\hline & $\begin{array}{l}\text { Uncultured soil } \\
\text { fungus }\end{array}$ & DQ420800 & 216 & 97 & & 1 & & & & & & & & & \\
\hline & $\begin{array}{l}\text { Uncultured soil } \\
\text { fungus }\end{array}$ & DQ420859 & 187 & 95 & 2 & & & & & & & & & & \\
\hline & $\begin{array}{l}\text { Uncultured soil } \\
\text { fungus }\end{array}$ & DQ420918 & 214 & 100 & I & & & & & & & & & & \\
\hline & $\begin{array}{l}\text { Uncultured soil } \\
\text { fungus }\end{array}$ & DQ42I065 & 255 & 100 & & & & & & & & & & I & \\
\hline & $\begin{array}{l}\text { Uncultured soil } \\
\text { fungus }\end{array}$ & DQ42I073 & 255 & 100 & & & & & 2 & & & & & & \\
\hline & $\begin{array}{l}\text { Uncultured soil } \\
\text { fungus }\end{array}$ & DQ42I079 & 259 & 100 & & & & & & & & & & 1 & \\
\hline & $\begin{array}{l}\text { Uncultured soil } \\
\text { fungus }\end{array}$ & DQ42I237 & 228 & $97-94$ & & & & & & & & & 1 & 2 & \\
\hline & $\begin{array}{l}\text { Uncultured soil } \\
\text { fungus }\end{array}$ & DQ42I243 & 249 & 99 & & & & & & & & & & & 1 \\
\hline & $\begin{array}{l}\text { Uncultured soil } \\
\text { fungus }\end{array}$ & DQ980584 & 218 & 100 & & & & & & & & I & & & \\
\hline & $\begin{array}{l}\text { Uncultured soil } \\
\text { fungus }\end{array}$ & EU675985 & 223 & $100-99$ & 1 & & 2 & & & & & & & 3 & \\
\hline & $\begin{array}{l}\text { Uncultured } \\
\text { soil fungus }\end{array}$ & EU826920 & 257 & $100-99$ & & & & & 1 & & & & & 3 & I \\
\hline Unidentified & OTU 87 & & 357 & & 1 & & & & & & & & & & \\
\hline 36 OTUs & OTU 34 & & 210 & & 1 & & & & & & & & & & \\
\hline \multirow[t]{14}{*}{84 clones } & OTU I4 & & 216 & & 2 & & & & & & & & & & \\
\hline & OTU 39 & & 234 & & I & & & & & & & & & & \\
\hline & OTU 66 & & 270 & & 1 & & & & & & & & & & \\
\hline & OTU 33 & & 301 & & & 1 & & & & & & & & & \\
\hline & OTU 20 & & 233 & & & 1 & & & & & & & & & \\
\hline & OTU I 3 & & 220 & & & 2 & & & & & & & & & \\
\hline & OTU 26 & & 352 & & & 1 & & & & & & & & & \\
\hline & OTU I04 & & 333 & & & I & & & & & & & & & \\
\hline & OTU 44 & & 429 & & & 5 & & & & & & & & & \\
\hline & OTU I05 & & 207 & & & 1 & & & & & & & & & \\
\hline & OTU 60 & & 239 & & & 2 & & & I & & & & & 3 & 2 \\
\hline & OTU 19 & & 234 & & & & I & & & & & & & & \\
\hline & OUT 2 & & 264 & & & & 2 & & & & & & & & \\
\hline & OTU 53 & & 213 & & & & 1 & & & & & & & & \\
\hline
\end{tabular}


Table SI (Continued)

\begin{tabular}{|c|c|c|c|c|c|c|c|c|c|c|c|c|c|c|c|}
\hline \multirow[t]{2}{*}{ Phylum } & \multirow{2}{*}{$\begin{array}{l}\text { Blast match/clone } \\
\text { name }\end{array}$} & \multirow{2}{*}{$\begin{array}{l}\text { Accession } \\
\text { number }\end{array}$} & \multirow{2}{*}{$\begin{array}{l}\text { ITS } \\
\text { size } \\
\text { (bp) }\end{array}$} & \multirow{2}{*}{$\begin{array}{l}\text { Identity } \\
\text { (\%) }\end{array}$} & \multicolumn{11}{|c|}{ Number of fungal ITS clones } \\
\hline & & & & & $\mathbf{K I}$ & K2 & $\mathbf{K} 3$ & K4 & A & B & C & D & $\mathbf{E}$ & $\mathbf{F}$ & G \\
\hline & OTU 54 & & 213 & & 5 & & 9 & I & & & & & & & \\
\hline & OTU 56 & & 223 & & & & I & 2 & & & & & & & \\
\hline & OTU 83 & & 426 & & & & 11 & & & & & & & & \\
\hline & OTU 85 & & 249 & & & & 4 & I & & & & & & & \\
\hline & OTU 45 & & 320 & & & & & I & & & & & & & \\
\hline & OTU 55 & & 235 & & & & & I & & & & & & & \\
\hline & OTU 72 & & 249 & & & & & I & & & & & & & \\
\hline & OTU 95 & & 352 & & & & & 2 & & & & & & & \\
\hline & OTU 86 & & 250 & & & & I & 2 & & & & & & & \\
\hline & OTU 108 & & 208 & & & & & & & & & I & & & \\
\hline & OTU 109 & & 259 & & & & & & & & & & & 1 & \\
\hline & OTU IIO & & $27 \mid$ & & & & & & & & & & 2 & & \\
\hline & OTU III & & 173 & & & & & & & $\mathrm{I}$ & & & & & \\
\hline & OTU II2 & & 263 & & & & & & & & & & I & & \\
\hline & OTU II3 & & 244 & & & & & & & & & & I & & \\
\hline & OTU II4 & & 196 & & & & & & & & & & & & I \\
\hline & OTU IIS & & 410 & & & & & & & & & & 1 & & \\
\hline & OTU II6 & & 351 & & & & & & & & & & I & & \\
\hline & OTU II7 & & 368 & & & & & & & & & & I & & \\
\hline & OTU II8 & & 228 & & & & & & & & & & & & I \\
\hline
\end{tabular}

Abbreviations: ITS, internal transcribed spacer; OTU, operational taxonomic unit; bp, base pair.

Table S2 Catalog of bacteria with the highest sequence similarity to clones by BLAST search and bacterial phyla classified by using Classifier of RDP-X

\begin{tabular}{|c|c|c|c|c|c|}
\hline Phylum & Clone name & Blast match & $\begin{array}{l}\text { Accession } \\
\text { number }\end{array}$ & $\begin{array}{l}\text { I6S rDNA } \\
\text { size (bp) }\end{array}$ & Identity (\%) \\
\hline Proteobacteria & BK5-17 & Aeromonas punctata & GU205।98 & 493 & 99 \\
\hline \multirow[t]{28}{*}{249 clones } & BC8-I, BK I0-25, F32 & Agricultural soil bacterium & AJ252663 & 487 & $100-99$ \\
\hline & BC5-16 & Alpha proteobacterium & D8462I & 434 & 98 \\
\hline & D33 & Beta proteobacterium & AYI6206I & 485 & 99 \\
\hline & $\mathrm{D} 27$ & Burkholderia spp & FJ478405 & 485 & 97 \\
\hline & BKII-3 & Hyphomicrobium & AB543807 & 434 & 99 \\
\hline & A47, A48 & Janthinobacterium lividum & AJ5852I8 & 487 & $100-99$ \\
\hline & $\mathrm{A} 53$ & Nitrosospira sp & AY 684260 & 485 & 99 \\
\hline & BK9-17 & Nordella sp & AM4II 927 & 436 & 99 \\
\hline & BC9- 15 & Pedomicrobium manganicum & GU269549 & 434 & 98 \\
\hline & F35 & Pseudomonas sp & $A B 461673$ & 485 & 100 \\
\hline & A54 & Pseudomonas sp. & EU681010 & 485 & 100 \\
\hline & GI4 & Pseudomonas sp & EU681013 & 485 & 99 \\
\hline & BKII-6 & Rhizosphere soil bacterium & AJ252704 & 500 & 97 \\
\hline & BK3-35 & Sorangium cellulosum & GU29904I & 500 & 99 \\
\hline & BKI0-33 & Sphingomonadaceae bacterium & AB269802 & 434 & 98 \\
\hline & BK8-44 & Uncultured Alcaligenaceae bacterium & AM936094 & 485 & 99 \\
\hline & D4I & Uncultured alpha proteobacterium & AY394616 & 432 & 100 \\
\hline & BC3-39 & Uncultured alpha proteobacterium & AY921760 & 431 & 99 \\
\hline & BKI2-39 & Uncultured alpha proteobacterium & AY921974 & 421 & 99 \\
\hline & BC5-42 & Uncultured alpha proteobacterium & FM252945 & 432 & 99 \\
\hline & BK9-36 & Uncultured alpha proteobacterium & FN594676 & 434 & 98 \\
\hline & BK5-12 & Uncultured bacterium & $A B \mid 86825$ & 444 & 95 \\
\hline & BKII-I5 & Uncultured bacterium & AF392673 & 483 & 100 \\
\hline & ВС3-25, ВС3-33 & Uncultured bacterium & AJ5764I9 & 497 & 97 \\
\hline & BC8-38 & Uncultured bacterium & AJ863370 & 434 & 99 \\
\hline & BKI2-46 & Uncultured bacterium & AMI58328 & 485 & 98 \\
\hline & D49 & Uncultured bacterium & AMI58355 & 485 & 97 \\
\hline & BK5-39 & Uncultured bacterium & AM909847 & 498 & 96 \\
\hline
\end{tabular}


Table S2 (Continued)

\begin{tabular}{|c|c|c|c|c|c|}
\hline Phylum & Clone name & Blast match & $\begin{array}{l}\text { Accession } \\
\text { number }\end{array}$ & $\begin{array}{l}\text { I6S rDNA } \\
\text { size (bp) }\end{array}$ & Identity (\%) \\
\hline & BK7-7 & Uncultured bacterium & AM9I0073 & 482 & 97 \\
\hline & E38 & Uncultured bacterium & AY425763 & 434 & 100 \\
\hline & BC8- 17 & Uncultured bacterium & AY917444 & 436 & 99 \\
\hline & ВС $3-37$, BK7-29 & Uncultured bacterium & DQ444030 & 504 & $98-97$ \\
\hline & B9 & Uncultured bacterium & DQ45I508 & 440 & 97 \\
\hline & BC3-35 & Uncultured bacterium & DQ8I5232 & 444 & 94 \\
\hline & D56 & Uncultured bacterium & EF0I8952 & 436 & 99 \\
\hline & $\mathrm{BC} 9-6$ & Uncultured bacterium & EF0I8996 & 432 & 97 \\
\hline & DI3 & Uncultured bacterium & EF0I9435 & 436 & 96 \\
\hline & BC8-37 & Uncultured bacterium & EFOI 9837 & 479 & 98 \\
\hline & BC7-34 & Uncultured bacterium & EF39290I & 436 & 99 \\
\hline & BC7-28 & Uncultured bacterium & EF474263 & 483 & 98 \\
\hline & B44 & Uncultured bacterium & EF492895 & 485 & 98 \\
\hline & BKI2-3I & Uncultured bacterium & EF5I 6458 & 501 & 95 \\
\hline & EI9 & Uncultured bacterium & EF5I 6473 & 487 & 98 \\
\hline & G8 & Uncultured bacterium & EF589979 & 444 & 100 \\
\hline & BKI0-20 & Uncultured bacterium & EF590047 & 434 & 99 \\
\hline & BK9-40 & Uncultured bacterium & EF65942I & 489 & 96 \\
\hline & BKI0-5, BKI0-8 & Uncultured bacterium & EUI33360 & 432 & 99 \\
\hline & BK8-24 & Uncultured bacterium & EUI 33467 & 432 & 99 \\
\hline & BC5-34 & Uncultured bacterium & EUI33479 & 432 & 98 \\
\hline & BKI0-12 & Uncultured bacterium & EUI33780 & 484 & 98 \\
\hline & BK9-8 & Uncultured bacterium & EUI33792 & 487 & 99 \\
\hline & BK9-48 & Uncultured bacterium & EUI33860 & 486 & 99 \\
\hline & B24, B28, BK7-47 & Uncultured bacterium & EUI34376 & 504 & $98-97$ \\
\hline & A36 & Uncultured bacterium & EUI34384 & 506 & 95 \\
\hline & BC7-26 & Uncultured bacterium & EUI34448 & 499 & 96 \\
\hline & G56 & Uncultured bacterium & EUI34453 & 504 & 96 \\
\hline & A56 & Uncultured bacterium & EUI34470 & 500 & 97 \\
\hline & B49 & Uncultured bacterium & EUI34472 & 499 & 97 \\
\hline & $\mathrm{BCI}-2$ & Uncultured bacterium & EUI34486 & 500 & 96 \\
\hline & BK4-10 & Uncultured bacterium & EUI34524 & 501 & 93 \\
\hline & E4I & Uncultured bacterium & EUI34528 & 504 & 97 \\
\hline & $\mathrm{A} 2$ & Uncultured bacterium & EUI34706 & 486 & 95 \\
\hline & BC7- 10 & Uncultured bacterium & EUI59984 & 485 & 98 \\
\hline & $\mathrm{Cl}$ & Uncultured bacterium & EUI60I36 & 487 & 99 \\
\hline & BC7-9 & Uncultured bacterium & EUI60209 & 488 & 97 \\
\hline & BK9-15 & Uncultured bacterium & EUI6033I & 499 & 98 \\
\hline & BK7-23 & Uncultured bacterium & EU280739 & 582 & 98 \\
\hline & Al8 & Uncultured bacterium & EU280747 & 400 & 96 \\
\hline & BK5-25 & Uncultured bacterium & EU3352I4 & 506 & 98 \\
\hline & BKII-I & Uncultured bacterium & EU335283 & 506 & 93 \\
\hline & $\mathrm{BC} 10-18$ & Uncultured bacterium & EU786|47 & 502 & 97 \\
\hline & $\mathrm{C} 20$ & Uncultured bacterium & EU869757 & 499 & 90 \\
\hline & BC3-44, BK I2-3 & Uncultured bacterium & EU88IIII & 434 & 99 \\
\hline & BC4-12 & Uncultured bacterium & EU88II66 & 437 & 99 \\
\hline & EI7 & Uncultured bacterium & EU88II 68 & 436 & 99 \\
\hline & BC8-42 & Uncultured bacterium & EU88II7I & 436 & 100 \\
\hline & $\mathrm{BCl} 0-2$ & Uncultured bacterium & EU88II83 & 498 & 97 \\
\hline & BKI2-22 & Uncultured bacterium & EU88I205 & 485 & 99 \\
\hline & BC4- 17 & Uncultured bacterium & EU88I293 & 499 & 95 \\
\hline & BK7-34 & Uncultured bacterium & EU88I332 & 499 & 98 \\
\hline & D50 & Uncultured bacterium & FJI7498I & 487 & 98 \\
\hline & $B C I I-17$ & Uncultured bacterium & FJI75095 & 484 & 99 \\
\hline & $\mathrm{BCI} 2-44$ & Uncultured bacterium & FJ390543 & 530 & 100 \\
\hline
\end{tabular}


Table S2 (Continued)

\begin{tabular}{|c|c|c|c|c|c|}
\hline Phylum & Clone name & Blast match & $\begin{array}{l}\text { Accession } \\
\text { number }\end{array}$ & $\begin{array}{l}\text { I6S rDNA } \\
\text { size (bp) }\end{array}$ & Identity (\%) \\
\hline & E28 & Uncultured bacterium & FJ409259 & 434 & 99 \\
\hline & $\mathrm{B} \mid 3$ & Uncultured bacterium & FJ409328 & 485 & 98 \\
\hline & BC9-9 & Uncultured bacterium & FJ444700 & 485 & 99 \\
\hline & BK9-16 & Uncultured bacterium & FJ478629 & 432 & 99 \\
\hline & BK9-47 & Uncultured bacterium & FJ478723 & 504 & 99 \\
\hline & $\mathrm{E} 46$ & Uncultured bacterium & FJ478734 & 434 & 99 \\
\hline & BKII-26, BKI2-26, & Uncultured bacterium & FJ478787 & 434 & $100-99$ \\
\hline & BK5-2, BK7-36, & & & & \\
\hline & BC6-48 & & & & \\
\hline & BK9-18 & Uncultured bacterium & FJ4788I8 & 487 & 99 \\
\hline & BK9-44 & Uncultured bacterium & FJ478838 & 482 & 100 \\
\hline & BKII-I3 & Uncultured bacterium & FJ479038 & 482 & 99 \\
\hline & E20, E47 & Uncultured bacterium & FJ47929I & 504 & 99 \\
\hline & BK6-3I & Uncultured bacterium & FJ479372 & 506 & 100 \\
\hline & B55 & Uncultured bacterium & FJ47944I & 484 & 98 \\
\hline & BKII-4I & Uncultured bacterium & FJ47944I & 484 & 94 \\
\hline & BC9-25 & Uncultured bacterium & FJ479505 & 484 & 98 \\
\hline & BK5-5 & Uncultured bacterium & FJ479545 & 434 & 99 \\
\hline & A55 & Uncultured bacterium & FJ479588 & 486 & 99 \\
\hline & BKIO-I3 & Uncultured bacterium & FJ479597 & 503 & 98 \\
\hline & $\mathrm{BCI} 0-6$ & Uncultured bacterium & FJ532345 & 495 & 94 \\
\hline & BKII-4 & Uncultured bacterium & FJ625364 & 446 & 98 \\
\hline & $\mathrm{BCI}-27$ & Uncultured bacterium & FJ7I9080 & 436 & 99 \\
\hline & D20, D5I & Uncultured bacterium & FM95682I & 436 & 99 \\
\hline & BKII-28 & Uncultured bacterium & FM956978 & 444 & 99 \\
\hline & $\mathrm{BCI} 2-7, \mathrm{BC} 8-7$ & Uncultured bacterium & $\mathrm{FN} 40 \mathrm{I} 278$ & 436 & $100-99$ \\
\hline & $\mathrm{BI} 4, \mathrm{~B} 6$ & Uncultured bacterium & GQ023358 & 436 & 99 \\
\hline & BC6-40 & Uncultured bacterium & GQ094003 & 444 & 98 \\
\hline & D47 & Uncultured bacterium & GQI27684 & 436 & 100 \\
\hline & $\mathrm{BCl} 0-3$ & Uncultured bacterium & GQ127692 & 495 & 97 \\
\hline & D22 & Uncultured bacterium & GQI27702 & 483 & 99 \\
\hline & BC8-27 & Uncultured bacterium & GQ128II6 & 498 & 97 \\
\hline & D38 & Uncultured bacterium & GQ128I56 & 487 & 99 \\
\hline & BK7-44 & Uncultured bacterium & GQ263248 & 504 & 97 \\
\hline & A35 & Uncultured bacterium & GQ263698 & 491 & 100 \\
\hline & BKII-I6 & Uncultured bacterium & GQ264I33 & 432 & 99 \\
\hline & BC7-47 & Uncultured bacterium & GQ264I4I & 489 & 88 \\
\hline & BC5-20 & Uncultured bacterium & GQ264I93 & 434 & 99 \\
\hline & AI0, A36, BC7-36, & Uncultured bacterium & GQ339232 & 485 & $99-98$ \\
\hline & BKI2-10, BK7-I2 & & & & \\
\hline & D55 & Uncultured bacterium & GQ376803 & 451 & 98 \\
\hline & BKI $2-45$ & Uncultured bacterium & GQ376892 & 504 & 97 \\
\hline & BK8-9 & Uncultured bacterium & GQ376899 & 436 & 99 \\
\hline & $\mathrm{A} / 3$ & Uncultured bacterium & GQ3769I3 & 487 & 100 \\
\hline & $\mathrm{BC} 3-5$ & Uncultured bacterium & GQ376963 & 444 & 100 \\
\hline & BC3-48, BK3-5I & Uncultured bacterium & GQ376972 & 434 & 96 \\
\hline & $\mathrm{C} 27$ & Uncultured bacterium & GQ376996 & 501 & 96 \\
\hline & $\mathrm{C} 45$ & Uncultured bacterium & GQ376996 & 501 & 92 \\
\hline & BK9-I4 & Uncultured bacterium & GQ46I66I & 485 & 99 \\
\hline & BC9-23 & Uncultured bacterium & GQ46I662 & 503 & 97 \\
\hline & E5I & Uncultured bacterium & GQ500733 & 484 & 100 \\
\hline & $\mathrm{BC}|0-| 3, \mathrm{BC} 7-3 \mid$ & Uncultured bacterium & GQ500738 & 445 & $99-98$ \\
\hline & B6I & Uncultured bacterium & GQ860038 & 507 & 95 \\
\hline & BK5-II & Uncultured bacterium & GQ860I22 & 444 & 100 \\
\hline & BC5-22 & Uncultured bacterium & GQ860I62 & 502 & 98 \\
\hline & BK3-19 & Uncultured bacterium & GQ996436 & 459 & 97 \\
\hline
\end{tabular}


Table S2 (Continued)

\begin{tabular}{|c|c|c|c|c|c|}
\hline Phylum & Clone name & Blast match & $\begin{array}{l}\text { Accession } \\
\text { number }\end{array}$ & $\begin{array}{l}\text { I6S rDNA } \\
\text { size (bp) }\end{array}$ & Identity (\%) \\
\hline & BK8-39 & Uncultured bacterium & GU256467 & 434 & 99 \\
\hline & BC5-24 & Uncultured bacterium & GU25648I & 491 & 100 \\
\hline & BC8-4 & Uncultured bacterium & GU272264 & 487 & 100 \\
\hline & BC5-25 & Uncultured bacterium & GU44406I & 453 & 96 \\
\hline & BK9-7 & Uncultured bacterium & GU444084 & 501 & 94 \\
\hline & BCII-39 & Uncultured bacterium & GU444098 & 487 & 99 \\
\hline & D25 & Uncultured beta proteobacterium & AB45I 788 & 485 & 99 \\
\hline & $\mathrm{E} 30$ & Uncultured beta proteobacterium & AY921700 & 484 & 99 \\
\hline & G55 & Uncultured beta proteobacterium & AY921788 & 483 & 95 \\
\hline & BCII-29 & Uncultured beta proteobacterium & AY922034 & 485 & 98 \\
\hline & BC6-2 & Uncultured beta proteobacterium & EU266802 & 484 & 99 \\
\hline & A4 & Uncultured beta proteobacterium & EU979050 & 485 & 99 \\
\hline & BC5-7, BK5-2I & Uncultured Bradyrhizobium sp & FJ4952I7 & 436 & 100 \\
\hline & BK9-2I & Uncultured Burkholderiales bacterium & AM935842 & 487 & 100 \\
\hline & BCII-7 & Uncultured Caulobacterales bacterium & EU665092 & 431 & 99 \\
\hline & F3 & Uncultured Cystobacteraceae bacterium & EF019208 & 500 & 98 \\
\hline & G40 & Uncultured delta proteobacterium & AM934955 & 506 & 99 \\
\hline & BKI0-47 & Uncultured delta proteobacterium & EF072538 & 488 & 96 \\
\hline & $\mathrm{BCI} 0-28$ & Uncultured delta proteobacterium & EF4I7732 & 504 & 94 \\
\hline & G26 & Uncultured delta proteobacterium & EF4I7746 & 504 & 99 \\
\hline & $\mathrm{C} 2, \mathrm{C} 5$ & Uncultured delta proteobacterium & EF651050 & 498 & 99 \\
\hline & $\mathrm{FI} 4$ & Uncultured delta proteobacterium & EF663249 & 504 & 99 \\
\hline & BK4-22 & Uncultured delta proteobacterium & EU30045I & 504 & 98 \\
\hline & BKII-44 & Uncultured delta proteobacterium & EU849397 & 499 & 92 \\
\hline & C58 & Uncultured delta proteobacterium & EU979075 & 498 & 98 \\
\hline & BK8-33 & Uncultured delta proteobacterium & FJ946562 & 491 & 89 \\
\hline & BC4-37, BK5-3I & Uncultured Desulfuromonadales bacterium & AM9349I5 & 504 & 97 \\
\hline & BC7-24 & Uncultured Desulfuromonadales bacterium & AM935776 & 504 & 99 \\
\hline & E49 & Uncultured eubacterium & AJ2928I7 & 436 & 97 \\
\hline & $\mathrm{C} 36$ & Uncultured Ferribacterium sp. & FMI76903 & 487 & 98 \\
\hline & $\mathrm{BC} 10-22$ & Uncultured Flavimonas sp & FMI7540I & 485 & 98 \\
\hline & EII & Uncultured forest soil bacterium & AY913276 & 456 & 94 \\
\hline & BC6-26, BC6-30 & Uncultured gamma proteobacterium & AM93521I & 502 & 100 \\
\hline & Al5 & Uncultured gamma proteobacterium & AY043794 & 489 & 94 \\
\hline & $\mathrm{FI}$ & Uncultured gamma proteobacterium & EFI8845I & 485 & 99 \\
\hline & BC6-19 & Uncultured gamma proteobacterium & EU979089 & 489 & 99 \\
\hline & BC9-12, E48 & Uncultured gamma proteobacterium & EU979089 & 488 & 96 \\
\hline & GI5, GI7 & Uncultured Geothermobacter sp & FMI76316 & 505 & 99 \\
\hline & BC7-4I & Uncultured Hyphomicrobiaceae bacterium & EU26680 & 432 & 100 \\
\hline & G50 & Uncultured Hyphomicrobiaceae bacterium & FM95682I & 436 & 99 \\
\hline & BC5-6, E44 & Uncultured Nitrosomonadaceae bacterium & EF019260 & 487 & $97-96$ \\
\hline & $\mathrm{A} 32$ & Uncultured Oxalobacteraceae bacterium & EF019185 & 483 & 99 \\
\hline & $\mathrm{BC} / 2-27$ & Uncultured proteobacterium & DQ828II2 & 436 & 99 \\
\hline & BC9-48, FII & Uncultured proteobacterium & DQ828343 & 485 & 98 \\
\hline & BK3-15 & Uncultured proteobacterium & DQ8284I3 & 522 & 91 \\
\hline & DI9 & Uncultured proteobacterium & DQ828444 & 487 & 97 \\
\hline & G7 & Uncultured proteobacterium & DQ828498 & 487 & 99 \\
\hline & E27 & Uncultured proteobacterium & DQ8285।8 & 504 & 99 \\
\hline & BC8-25 & Uncultured proteobacterium & DQ8290I5 & 445 & 95 \\
\hline & BK3-33 & Uncultured proteobacterium & DQ829067 & 434 & 99 \\
\hline & BC9-37 & Uncultured proteobacterium & DQ829215 & 506 & 97 \\
\hline & BK4-I & Uncultured proteobacterium & DQ829395 & 506 & 95 \\
\hline & $B C I I-10$ & Uncultured proteobacterium & DQ829567 & 539 & 98 \\
\hline & D28, D52 & Uncultured proteobacterium & EF0I9038 & 487 & 98 \\
\hline & B5I & Uncultured proteobacterium & EF0I9739 & 482 & 98 \\
\hline & BKI2-5 & Uncultured proteobacterium & EU297804 & 510 & 98 \\
\hline
\end{tabular}


Table S2 (Continued)

\begin{tabular}{|c|c|c|c|c|c|}
\hline Phylum & Clone name & Blast match & $\begin{array}{l}\text { Accession } \\
\text { number }\end{array}$ & $\begin{array}{l}\text { I6S rDNA } \\
\text { size (bp) }\end{array}$ & Identity (\%) \\
\hline & $\mathrm{BC}|2-4|$ & Uncultured proteobacterium & EU299489 & 498 & 98 \\
\hline & BC9-8 & Uncultured proteobacterium & EU29984I & 502 & 97 \\
\hline & G4I & Uncultured Rhodobium sp & GU55646I & 446 & 97 \\
\hline & $\mathrm{BC} 10-15$ & Uncultured Rhodocyclaceae bacterium & EF019009 & 482 & 98 \\
\hline & C34 & Uncultured soil bacterium & AF423222 & 485 & 99 \\
\hline & BK7-20 & Uncultured soil bacterium & AM884623 & 485 & 99 \\
\hline & $\mathrm{A} 20$ & Uncultured soil bacterium & AY24270I & 487 & 99 \\
\hline & $\mathrm{BCI}$ 0-37, BK8-42 & Uncultured soil bacterium & AY242719 & 485 & $98-97$ \\
\hline & BK7-46 & Uncultured soil bacterium & AY493946 & 486 & 98 \\
\hline & B29, BC4-5 & Uncultured soil bacterium & DQI28467 & 537 & $98-97$ \\
\hline & BCII-18 & Uncultured soil bacterium & DQI54524 & 487 & 99 \\
\hline & BC3-19 & Uncultured soil bacterium & DQI5465I & 485 & 99 \\
\hline & $\mathrm{BC} 10-45, \mathrm{BC} 4-25$ & Uncultured soil bacterium & DQ297965 & 504 & 98 \\
\hline & F26 & Uncultured soil bacterium & DQ6437I8 & 491 & 100 \\
\hline & F34 & Uncultured soil bacterium & DQ643724 & 491 & 100 \\
\hline & BK7-45 & Uncultured soil bacterium & GQ918964 & 496 & 93 \\
\hline & $\mathrm{A} 30$ & Uncultured soil bacterium & GU374985 & 485 & 98 \\
\hline & BC9-16, BKII-12 & Uncultured soil bacterium & GU375476 & 504 & 99 \\
\hline & BC3-30 & Uncultured Sphingomonas sp & AM93649I & 433 & 98 \\
\hline & BC3-10 & Uncultured Thermus sp & DQ2016II & 482 & 96 \\
\hline Acidobacteria & BK8-48 & Agricultural soil bacterium & AJ252612 & 502 & 96 \\
\hline \multirow[t]{35}{*}{236 clones } & BC9-18 & Bacterial species & Z95736 & 499 & 99 \\
\hline & BK5-5I & Bacterial species & Z95734 & 501 & 99 \\
\hline & BKII-23 & Uncultured Acidobacteria bacterium & GQI 20660 & 501 & 99 \\
\hline & $\mathrm{BC} 6-7$ & Uncultured Acidobacteria bacterium & GQI20636 & 501 & 98 \\
\hline & D26 & Uncultured Acidobacteria bacterium & FMI76437 & 502 & 99 \\
\hline & $\mathrm{FI} 6$ & Uncultured Acidobacteria bacterium & FJ478655 & 500 & 99 \\
\hline & BK7-8 & Uncultured Acidobacteria bacterium & EU979I05 & 498 & 99 \\
\hline & BK5-24 & Uncultured Acidobacteria bacterium & EU426462 & 474 & 97 \\
\hline & $B K 12-13$ & Uncultured Acidobacteria bacterium & EU425874 & 500 & 97 \\
\hline & E29 & Uncultured Acidobacteria bacterium & EU425837 & 499 & 98 \\
\hline & Al7 & Uncultured Acidobacteria bacterium & EUI22945 & 502 & 97 \\
\hline & BK-18 & Uncultured Acidobacteria bacterium & EUI22922 & 501 & 99 \\
\hline & C5I & Uncultured Acidobacteria bacterium & EUI 22900 & 501 & 99 \\
\hline & A45 & Uncultured Acidobacteria bacterium & EUI22894 & 501 & 97 \\
\hline & BC9-46 & Uncultured Acidobacteria bacterium & EUI 22854 & 448 & 98 \\
\hline & BK8-29 & Uncultured Acidobacteria bacterium & EUI22809 & 500 & 98 \\
\hline & G28 & Uncultured Acidobacteria bacterium & EUI22663 & 499 & 99 \\
\hline & $\mathrm{C} 40$ & Uncultured Acidobacteria bacterium & EUI22654 & 501 & 99 \\
\hline & BC5-30 & Uncultured Acidobacteria bacterium & EF664394 & 240 & 95 \\
\hline & B43 & Uncultured Acidobacteria bacterium & EF457455 & 502 & 96 \\
\hline & BK4-27 & Uncultured Acidobacteria bacterium & EF457425 & 499 & 98 \\
\hline & BC9-36 & Uncultured Acidobacteria bacterium & EF457400 & 444 & 99 \\
\hline & $\mathrm{Cl}$ & Uncultured Acidobacteria bacterium & EF4573I8 & 498 & 97 \\
\hline & $\mathrm{D} 30$ & Uncultured Acidobacteria bacterium & EF447092 & 497 & 98 \\
\hline & BKI0-3 & Uncultured Acidobacteria bacterium & EF4I770I & 481 & 99 \\
\hline & F44, F48 & Uncultured Acidobacteria bacterium & EF0I9093 & 450 & 99 \\
\hline & D35 & Uncultured Acidobacteria bacterium & DQ82883। & 501 & 99 \\
\hline & $\mathrm{B} 10$ & Uncultured Acidobacteria bacterium & DQ828203 & 499 & 99 \\
\hline & BC6-24 & Uncultured Acidobacteria bacterium & DQ828I34 & 501 & 98 \\
\hline & BK4-18, BK4-19 & Uncultured Acidobacteria bacterium & DQ648900 & 501 & 96 \\
\hline & BKII-2I & Uncultured Acidobacteria bacterium & AY9218II & 518 & 95 \\
\hline & BK9-I & Uncultured Acidobacteria bacterium & AY214902 & 501 & 98 \\
\hline & A39 & Uncultured Acidobacteria bacterium & AM936904 & 498 & 99 \\
\hline & G45 & Uncultured Acidobacteriaceae bacterium & FMI76935 & $47 \mid$ & 98 \\
\hline & $\mathrm{C} 26$ & Uncultured Acidobacteriaceae bacterium & FMI76753 & 501 & 99 \\
\hline
\end{tabular}


Table S2 (Continued)

\begin{tabular}{|c|c|c|c|c|c|}
\hline Phylum & Clone name & Blast match & $\begin{array}{l}\text { Accession } \\
\text { number }\end{array}$ & $\begin{array}{l}\text { I6S rDNA } \\
\text { size (bp) }\end{array}$ & Identity (\%) \\
\hline & B46, C57 & Uncultured Acidobacteriaceae bacterium & FMI75766 & 506 & 98 \\
\hline & B56 & Uncultured Acidobacteriaceae bacterium & EF018918 & 464 & 98 \\
\hline & $\mathrm{BCl}$ 0-7, BC7-46 & Uncultured Acidobacteriaceae bacterium & AM936873 & 501 & 99 \\
\hline & BK4-17 & Uncultured Acidobacteriaceae bacterium & AM936618 & 501 & 99 \\
\hline & F22 & Uncultured Acidobacteriaceae bacterium & AM936458 & 501 & 99 \\
\hline & $\mathrm{Al}$ & Uncultured Acidobacteriaceae bacterium & AM936237 & 337 & 100 \\
\hline & BK5-33 & Uncultured Acidobacteriaceae bacterium & AM9355I6 & 501 & 99 \\
\hline & BK9-46 & Uncultured Acidobacteriaceae bacterium & AM935398 & 464 & 99 \\
\hline & BK5-9 & Uncultured Acidobacteriales bacterium & EU2765I0 & 498 & 99 \\
\hline & BK4-28 & Uncultured Acidobacteriales bacterium & EU202808 & 472 & 98 \\
\hline & BK8-II & Uncultured Acidobacteriales bacterium & AYI50900 & 499 & 97 \\
\hline & BK3-9 & Uncultured Acidobacteriales bacterium & AM9357II0 & 472 & 98 \\
\hline & BK5-19 & Uncultured Acidobacteriales bacterium & AM934745 & 501 & 99 \\
\hline & $\mathrm{BCI} 2-36$ & Uncultured acidobacterium & GQ302590 & 481 & 97 \\
\hline & BC7-II & Uncultured acidobacterium & FM866294 & 501 & 98 \\
\hline & BC4-I & Uncultured acidobacterium & GQ302590 & 481 & 97 \\
\hline & D36 & Uncultured bacterium & GU444075 & 499 & 98 \\
\hline & B2 & Uncultured bacterium & GU366872 & 464 & 99 \\
\hline & BK7-40 & Uncultured bacterium & GU359096 & 501 & 99 \\
\hline & BKI0-27 & Uncultured bacterium & GU359062 & 501 & 99 \\
\hline & BKI2-I & Uncultured bacterium & GU32602I & 501 & 99 \\
\hline & BC9-38 & Uncultured bacterium & GQ859685 & 501 & 99 \\
\hline & BC3-7 & Uncultured bacterium & GQ376990 & 479 & 98 \\
\hline & D24 & Uncultured bacterium & GQ376970 & 501 & 97 \\
\hline & G64 & Uncultured bacterium & GQ376702 & 500 & 99 \\
\hline & DI8 & Uncultured bacterium & GQ376578 & 479 & 97 \\
\hline & $\mathrm{C} 22$ & Uncultured bacterium & GQ264008 & 500 & 96 \\
\hline & $\mathrm{C} 23$ & Uncultured bacterium & GQI28004 & 501 & 96 \\
\hline & $\mathrm{A} 12$ & Uncultured bacterium & GQ127804 & 476 & 97 \\
\hline & BC7-30 & Uncultured bacterium & GQ0I543I & 465 & 99 \\
\hline & $B C 6-12$ & Uncultured bacterium & FN565564 & 463 & 96 \\
\hline & $\mathrm{Cl} 2$ & Uncultured bacterium & FN56556I & 501 & 98 \\
\hline & $\mathrm{BC} 6-27$ & Uncultured bacterium & FN4340I6 & 463 & 99 \\
\hline & BK7-33 & Uncultured bacterium & FN40I 235 & 465 & 99 \\
\hline & BK8-37 & Uncultured bacterium & $\mathrm{FN} 401214$ & 465 & 99 \\
\hline & ВС3-14, ВС3-29, & Uncultured bacterium & FM956949 & 501 & $99-97$ \\
\hline & $\begin{array}{l}\text { ВC8-13, BK6-12, } \\
\text { BK8-47, BK9-35, G33 }\end{array}$ & & & & \\
\hline & F33 & Uncultured bacterium & FM956340 & 501 & 98 \\
\hline & $\mathrm{C} 30$ & Uncultured bacterium & FJ891039 & 444 & 90 \\
\hline & BK $10-42$ & Uncultured bacterium & FJ479576 & 501 & 98 \\
\hline & F28 & Uncultured bacterium & FJ479553 & 502 & 99 \\
\hline & $\begin{array}{l}\text { BC9-45, BK9-43, } \\
\text { F38, G2। }\end{array}$ & Uncultured bacterium & FJ479522 & 501 & $100-98$ \\
\hline & BC4-7, BK6-42 & Uncultured bacterium & FJ4795I8 & 500 & 99 \\
\hline & C44, C52 & Uncultured bacterium & FJ479465 & 501 & 94 \\
\hline & F24 & Uncultured bacterium & FJ479406 & 500 & 98 \\
\hline & BK9-38, F9 & Uncultured bacterium & FJ479374 & 472 & 99-98 \\
\hline & BK4-42 & Uncultured bacterium & FJ479328 & 481 & 98 \\
\hline & $\mathrm{BCI} I-22$ & Uncultured bacterium & FJ479I69 & 498 & 99 \\
\hline & B47 & Uncultured bacterium & FJ479I54 & 474 & 98 \\
\hline & BK9-II & Uncultured bacterium & FJ479073 & 498 & 99 \\
\hline & BC9-4 & Uncultured bacterium & FJ479064 & 501 & 98 \\
\hline & BC9-4I, E3 & Uncultured bacterium & FJ479059 & 498 & 99 \\
\hline & BC7-44, BK I0-15 & Uncultured bacterium & FJ479043 & 501 & 99 \\
\hline & BC6-23 & Uncultured bacterium & FJ478777 & 499 & 98 \\
\hline
\end{tabular}


Table S2 (Continued)

\begin{tabular}{|c|c|c|c|c|c|}
\hline Phylum & Clone name & Blast match & $\begin{array}{l}\text { Accession } \\
\text { number }\end{array}$ & $\begin{array}{l}\text { I6S rDNA } \\
\text { size (bp) }\end{array}$ & Identity (\%) \\
\hline & D58 & Uncultured bacterium & FJ478732 & 501 & 97 \\
\hline & F2I & Uncultured bacterium & FJ478677 & 498 & 98 \\
\hline & $\begin{array}{l}\text { ВC6-38, ВK8-25, } \\
\text { ВK9-32, ВK9-9 }\end{array}$ & Uncultured bacterium & FJ478667 & 501 & 99 \\
\hline & BKI0-39, C48 & Uncultured bacterium & FJ478655 & 500 & $99-98$ \\
\hline & BK8-30 & Uncultured bacterium & FJ478638 & 501 & 100 \\
\hline & BK7-30 & Uncultured bacterium & FJ478570 & 501 & 99 \\
\hline & BK6-36 & Uncultured bacterium & FJ47855I & 499 & 98 \\
\hline & BK8-7 & Uncultured bacterium & FJ444739 & 501 & 99 \\
\hline & BC6-14 & Uncultured bacterium & FJ444736 & 500 & 98 \\
\hline & BCII-44, BK4-3 & Uncultured bacterium & FJ44466I & 501 & 99 \\
\hline & BC8-36 & Uncultured bacterium & FJ409404 & 466 & 100 \\
\hline & $B C 5-14$ & Uncultured bacterium & FJ409367 & 501 & 97 \\
\hline & BC7-17 & Uncultured bacterium & FJ409345 & 499 & 98 \\
\hline & BC8-14 & Uncultured bacterium & FJI75106 & 481 & 97 \\
\hline & BC4-18, BK3-38, & Uncultured bacterium & EU88I338 & 501 & $99-97$ \\
\hline & BK7-13 & & & & \\
\hline & BK7-22 & Uncultured bacterium & EU88|27| & 500 & 98 \\
\hline & A34 & Uncultured bacterium & EU88I240 & 447 & 98 \\
\hline & BC6-4I, BKI0-II & Uncultured bacterium & EU88II2I & 474 & 99 \\
\hline & $\mathrm{BCI} 2-9, \mathrm{BK} 3-12$ & Uncultured bacterium & EU88III5 & 474 & 98 \\
\hline & E23 & Uncultured bacterium & EU88I094 & 499 & 99 \\
\hline & B48 & Uncultured bacterium & EU680444 & 478 & 100 \\
\hline & C42 & Uncultured bacterium & EU680399 & 488 & 94 \\
\hline & BC6-10 & Uncultured bacterium & EU669643 & 501 & 100 \\
\hline & $\mathrm{FI} 2$ & Uncultured bacterium & EU669608 & 501 & 98 \\
\hline & BK7-38 & Uncultured bacterium & EU428874 & 501 & 93 \\
\hline & BC5-44, G30, G39 & Uncultured bacterium & EU335268 & 500 & 99 \\
\hline & BK4-I5 & Uncultured bacterium & EU335199 & 466 & 98 \\
\hline & $\mathrm{C} 60$ & Uncultured bacterium & EU335I89 & 501 & 98 \\
\hline & BC6-2I, G20 & Uncultured bacterium & EU284522 & 501 & $98-96$ \\
\hline & BK6-24 & Uncultured bacterium & EU280609 & 503 & 94 \\
\hline & BC7-32 & Uncultured bacterium & EU280600 & 501 & 99 \\
\hline & BII & Uncultured bacterium & EU280558 & 501 & 97 \\
\hline & BC7-2 & Uncultured bacterium & EU234580 & 481 & 96 \\
\hline & A37 & Uncultured bacterium & EUI60390 & 466 & 99 \\
\hline & AlI, B2I & Uncultured bacterium & EUI60II4 & 499 & $99-98$ \\
\hline & BC4-36 & Uncultured bacterium & EUI600I7 & 502 & 99 \\
\hline & Al6, E43, FI9, F47 & Uncultured bacterium & EUI59978 & 501 & 99 \\
\hline & BK8-32 & Uncultured bacterium & EUI 32830 & 507 & 95 \\
\hline & BC3-1I & Uncultured bacterium & EUI 32407 & 496 & 95 \\
\hline & $\mathrm{BC} 12-42$ & Uncultured bacterium & EUI32236 & 481 & 95 \\
\hline & C56 & Uncultured bacterium & EUI322II & 498 & 96 \\
\hline & BC5-39 & Uncultured bacterium & EUI32I 23 & 468 & 99 \\
\hline & BC6-22 & Uncultured bacterium & EUI32093 & 506 & 90 \\
\hline & BKII-48 & Uncultured bacterium & EUI 32022 & 481 & 96 \\
\hline & BKI0-9 & Uncultured bacterium & EUI320I5 & 483 & 97 \\
\hline & BC8-3, BKI2-12, F5 & Uncultured bacterium & EU131964 & 501 & $100-98$ \\
\hline & BC9-3, BK5- 18 & Uncultured bacterium & EU131918 & 500 & 99 \\
\hline & GIO & Uncultured bacterium & EU044327 & 469 & 96 \\
\hline & G63 & Uncultured bacterium & EF600574 & 448 & 99 \\
\hline & BC5-46, BC5-47 & Uncultured bacterium & EF589982 & 466 & 99 \\
\hline & A33, B58 & Uncultured bacterium & EF494375 & 501 & 97 \\
\hline & G5 & Uncultured bacterium & EF49428I & 478 & 99 \\
\hline & BI7, B4I & Uncultured bacterium & EF492945 & 474 & 99 \\
\hline & BK4-I3, D48 & Uncultured bacterium & EF474272 & 487 & $97-96$ \\
\hline
\end{tabular}


Table S2 (Continued)

\begin{tabular}{|c|c|c|c|c|c|}
\hline Phylum & Clone name & Blast match & $\begin{array}{l}\text { Accession } \\
\text { number }\end{array}$ & $\begin{array}{l}\text { I6S rDNA } \\
\text { size (bp) }\end{array}$ & Identity (\%) \\
\hline & $\mathrm{BK} 6-33, \mathrm{Cl} 6$ & Uncultured bacterium & EF019724 & 461 & 99 \\
\hline & E33 & Uncultured bacterium & EF0I8839 & 501 & 98 \\
\hline & D2 & Uncultured bacterium & EF0I8668 & 501 & 97 \\
\hline & $\mathrm{BCI} 2-6$ & Uncultured bacterium & EF0I8599 & 501 & 98 \\
\hline & D42 & Uncultured bacterium & EF0I853। & 501 & 99 \\
\hline & G29 & Uncultured bacterium & DQ833485 & 450 & 95 \\
\hline & G5I & Uncultured bacterium & DQ463237 & 475 & 94 \\
\hline & BK7-32 & Uncultured bacterium & DQ404682 & 501 & 99 \\
\hline & BKII-3I & Uncultured bacterium & AY375053 & 506 & 94 \\
\hline & BC3-18 & Uncultured bacterium & AY221067 & 487 & 95 \\
\hline & B40 & Uncultured bacterium & AM909923 & 502 & 97 \\
\hline & BK4-3I & Uncultured bacterium & AJ876730 & 497 & 98 \\
\hline & BK9-20 & Uncultured bacterium & A]863264 & 498 & 98 \\
\hline & G62 & Uncultured bacterium & AJ8632I6 & 500 & 97 \\
\hline & E54 & Uncultured bacterium & AB20I600 & 501 & 98 \\
\hline & $\mathrm{Cll}$ & Uncultured Firmicutes bacterium & EU300237 & 501 & 99 \\
\hline & G46, G49 & Uncultured proteobacterium & EF662498 & 507 & 97 \\
\hline & $\mathrm{FIO}, \mathrm{F} 3 \mathrm{I}$ & Uncultured soil bacterium & GU375852 & 496 & 100 \\
\hline & $\mathrm{BC} 10-30$ & Uncultured soil bacterium & GU375843 & 472 & 99 \\
\hline & F53 & Uncultured soil bacterium & GU375570 & 500 & 100 \\
\hline & BC3-2I & Uncultured soil bacterium & GU375568 & 479 & 96 \\
\hline & BC6-46 & Uncultured soil bacterium & GU375540 & 501 & 97 \\
\hline & BC7-29 & Uncultured soil bacterium & EU58926I & 481 & 97 \\
\hline & BC9-27, FI3 & Uncultured soil bacterium & EU554636 & 500 & $99-97$ \\
\hline & BK3-27 & Uncultured soil bacterium & EF688387 & 448 & 98 \\
\hline & BK6-28 & Uncultured soil bacterium & EF494375 & 501 & 97 \\
\hline & $\mathrm{BCI} 0-14$ & Uncultured soil bacterium & EF4554I4 & 464 & 100 \\
\hline & BC7-37 & Uncultured soil bacterium & EF455264 & 501 & 98 \\
\hline & D9 & Uncultured soil bacterium & DQI54624 & 500 & 99 \\
\hline & B38, BKII-38 & Uncultured soil bacterium & DQI54600 & 501 & $98-96$ \\
\hline & BC4-9, F25 & Uncultured soil bacterium & DQI54585 & 501 & 99 \\
\hline & $\mathrm{C} 37$ & Uncultured soil bacterium & DQI54455 & 481 & 96 \\
\hline & $\mathrm{B} 16, \mathrm{~B} 7$ & Uncultured soil bacterium & DQI54434 & 498 & $99-98$ \\
\hline & A5, G48 & Uncultured soil bacterium & DQI54390 & 501 & 97 \\
\hline & $\mathrm{BCI} 0-25$ & Uncultured soil bacterium & DQI 28777 & 461 & 99 \\
\hline & BKI2-20, BK7-37 & Uncultured soil bacterium & AY989076 & 503 & 98 \\
\hline & BK9-3I & Uncultured soil bacterium & AY98866I & 501 & 97 \\
\hline & B30 & Uncultured soil bacterium & AY493920 & 472 & 98 \\
\hline & BC9-42 & Uncultured soil bacterium & AY32653I & 466 & 100 \\
\hline & D5 & Unidentified bacterium & EF605742 & 503 & 99 \\
\hline & BC7-20, EI2 & Unidentified bacterium & EF6057I9 & 498 & 98 \\
\hline & BC7-2I & Unidentified bacterium & EF221 047 & 501 & 98 \\
\hline Bacteroidetes & $\mathrm{EI} 4$ & Flavobacterium sp & AJ319019 & 479 & 98 \\
\hline \multirow[t]{13}{*}{56 clones } & A6, A4I & Flavobacterium sp & AM934654 & 479 & 97 \\
\hline & BKI2-8, BK5-I5 & Rhizosphere soil bacterium & AJ252690 & 484 & $97-96$ \\
\hline & BK8-40 & Sphingoterra bacterium & AB267719 & 483 & 95 \\
\hline & E2 & Uncultured alpha proteobacterium & EU979053 & 489 & 99 \\
\hline & DI4 & Uncultured bacterium & AMI58409 & 481 & 97 \\
\hline & G53 & Uncultured bacterium & DQ444033 & 489 & 100 \\
\hline & BC8-48 & Uncultured bacterium & EF020I37 & 485 & 96 \\
\hline & BK5-6 & Uncultured bacterium & EF378I63 & 479 & 99 \\
\hline & BK5-16 & Uncultured bacterium & EF378437 & 485 & 99 \\
\hline & BC8-3I & Uncultured bacterium & EF393429 & 492 & 98 \\
\hline & BK8-3। & Uncultured bacterium & EF516306 & 487 & 96 \\
\hline & BK7-18 & Uncultured bacterium & EUI33670 & 491 & 99 \\
\hline & $\mathrm{BCI} 2-33$ & Uncultured bacterium & EU1337/3 & 484 & 96 \\
\hline
\end{tabular}


Table S2 (Continued)

\begin{tabular}{|c|c|c|c|c|c|}
\hline Phylum & Clone name & Blast match & $\begin{array}{l}\text { Accession } \\
\text { number }\end{array}$ & $\begin{array}{l}\text { I6S rDNA } \\
\text { size (bp) }\end{array}$ & Identity (\%) \\
\hline & BK9-5 & Uncultured bacterium & EUI3373I & 485 & 95 \\
\hline & BK9-42 & Uncultured bacterium & EUI6035I & 482 & 98 \\
\hline & BC5-2 & Uncultured bacterium & EU21897I & 484 & 95 \\
\hline & BK9-13 & Uncultured bacterium & EU280678 & 486 & 97 \\
\hline & BK8-3 & Uncultured bacterium & EU43I 776 & 489 & 98 \\
\hline & BC5-3I & Uncultured bacterium & EU7I5822 & 491 & 100 \\
\hline & $\begin{array}{l}\text { BC9-19, BC9-33, } \\
\text { BK4-29 }\end{array}$ & Uncultured bacterium & EU88II 86 & 484 & 95 \\
\hline & $\mathrm{BCI}-25$ & Uncultured bacterium & FJI75022 & 484 & 96 \\
\hline & BK9-37 & Uncultured bacterium & FJ4405I2 & 484 & 96 \\
\hline & $\mathrm{BC} 10-16, \mathrm{BC}-46$ & Uncultured bacterium & FJ478792 & 491 & $97-95$ \\
\hline & BC4-I4 & Uncultured bacterium & FJ478792 & 491 & 97 \\
\hline & $\mathrm{BClO}-8$ & Uncultured bacterium & FM20II03 & 485 & 96 \\
\hline & BK9-23 & Uncultured bacterium & GQ202640 & 491 & 98 \\
\hline & D23 & Uncultured bacterium & GQ376555 & 491 & 94 \\
\hline & BC9-17 & Uncultured bacterium & GU256508 & 483 & 97 \\
\hline & $\begin{array}{l}\mathrm{BCI} 2-13, \mathrm{BC} 9-47 \\
\text { ВK3-13 }\end{array}$ & Uncultured bacterium & GU2565I0 & 483 & 99 \\
\hline & BKI0-43 & Uncultured Bacteroidetes bacterium & AM935033 & 484 & 93 \\
\hline & $\begin{array}{l}\text { ВС3-38, BK3-49, } \\
\text { BK7-14 }\end{array}$ & Uncultured Bacteroidetes bacterium & AY921902 & 489 & 97 \\
\hline & $\mathrm{BCl} 0-42$ & Uncultured Bacteroidetes bacterium & AY921967 & 491 & 99 \\
\hline & BK9-3 & Uncultured Bacteroidetes bacterium & EF0I8676 & 485 & 98 \\
\hline & BC4-35 & Uncultured Flavobacterium spp & DQ628948 & 479 & 95 \\
\hline & BC4-43 & Uncultured soil bacterium & AY037572 & 479 & 98 \\
\hline & BK9-45 & Uncultured soil bacterium & AY037613 & 484 & 97 \\
\hline & BK7-27 & Uncultured soil bacterium & AY493953 & 484 & 92 \\
\hline & BK6-35 & Uncultured soil bacterium & AY98873I & 491 & 95 \\
\hline & BK4-37 & Uncultured soil bacterium & DQ643677 & 483 & 100 \\
\hline & BC7-42, G4 & Uncultured soil bacterium & EF455I00 & 484 & $98-97$ \\
\hline & BK6-15 & Uncultured soil bacterium & GU375722 & 484 & 98 \\
\hline & $\mathrm{A} 25$ & Uncultured Sphingobacteriales bacterium & FJ536888 & 487 & 98 \\
\hline & BC6-35 & Uncultured unclassified bacterium & CU921805 & 486 & 94 \\
\hline & BKI2-9, BK8-26 & $\begin{array}{l}\text { Uncultured yard-trimming-compost } \\
\text { bacterium }\end{array}$ & AY0954II & 483 & 96 \\
\hline Verrucomicrobia & $\mathrm{BCI}-2 \mathrm{I}$ & Rhizosphere soil bacterium & A) 252700 & 491 & 97 \\
\hline \multirow[t]{18}{*}{70 clones } & BK4-I4 & Uncultured bacterium & $A B \mid 79534$ & 463 & 98 \\
\hline & D32 & Uncultured bacterium & AJ863246 & 507 & 92 \\
\hline & BK4-26 & Uncultured bacterium & AM490658 & 507 & 99 \\
\hline & BC8-8 & Uncultured bacterium & AY218557 & 509 & 95 \\
\hline & BK9-22 & Uncultured bacterium & DQ52I 482 & 507 & 96 \\
\hline & G59 & Uncultured bacterium & EF0193I5 & 507 & 95 \\
\hline & $\mathrm{F} 23$ & Uncultured bacterium & EF492973 & 493 & 99 \\
\hline & BK6-44 & Uncultured bacterium & EF5I6676 & 507 & 99 \\
\hline & $\mathrm{Al} 4$ & Uncultured bacterium & EF600576 & 501 & 98 \\
\hline & BC5-19 & Uncultured bacterium & EUI354I6 & 502 & 95 \\
\hline & BC9-II & Uncultured bacterium & EUI354I7 & 491 & 95 \\
\hline & BC5-5 & Uncultured bacterium & EUI35425 & 507 & 99 \\
\hline & BK5-26 & Uncultured bacterium & EUI35432 & 507 & 98 \\
\hline & $\begin{array}{l}\mathrm{B} 5, \mathrm{BC} I 0-10 \\
\mathrm{BC} 9-31, \mathrm{BK} 12-19\end{array}$ & Uncultured bacterium & EUI35436 & 507 & $99-97$ \\
\hline & BK8-6 & Uncultured bacterium & EUI35478 & 507 & 98 \\
\hline & BK7-43 & Uncultured bacterium & EUI35494 & 509 & 99 \\
\hline & B54 & Uncultured bacterium & EUI35506 & 508 & 91 \\
\hline & $\begin{array}{l}\text { BK4-2I, BK6-I, } \\
\text { BK6-10, BK7-48 }\end{array}$ & Uncultured bacterium & EU284207 & 507 & $97-96$ \\
\hline
\end{tabular}


Table S2 (Continued)

\begin{tabular}{|c|c|c|c|c|c|}
\hline Phylum & Clone name & Blast match & $\begin{array}{l}\text { Accession } \\
\text { number }\end{array}$ & $\begin{array}{l}\text { I6S rDNA } \\
\text { size (bp) }\end{array}$ & Identity (\%) \\
\hline & B45, G37, G42 & Uncultured bacterium & EU335I50 & 509 & $96-95$ \\
\hline & BC7-48, BK9-12 & Uncultured bacterium & EU335I82 & 507 & $99-98$ \\
\hline & BKI2-I4, BKI2-43 & Uncultured bacterium & EU74673I & 507 & 97 \\
\hline & BK7-39 & Uncultured bacterium & EU88I 208 & 502 & 99 \\
\hline & BK9-2 & Uncultured bacterium & FJ409284 & 524 & 95 \\
\hline & BC5-43, BC5-48 & Uncultured bacterium & FJ40938I & 498 & 93 \\
\hline & BK9-39 & Uncultured bacterium & FJ4785I9 & 507 & 99 \\
\hline & BC4-8, BK5-46, F42 & Uncultured bacterium & FJ4787II & 507 & $100-98$ \\
\hline & BK3-2 & Uncultured bacterium & FJ4787II & 507 & 95 \\
\hline & BC6-42 & Uncultured bacterium & FJ479069 & 507 & 98 \\
\hline & $\mathrm{BCI} 2-15$ & Uncultured bacterium & FJ479252 & 506 & 99 \\
\hline & BC7-33 & Uncultured bacterium & FJ479285 & 507 & 97 \\
\hline & A24 & Uncultured bacterium & GQ127764 & 502 & 96 \\
\hline & BC6-34 & Uncultured bacterium & GQ128057 & 500 & 91 \\
\hline & BC5-12, BK9-27 & Uncultured bacterium & GQ264267 & 485 & 98 \\
\hline & BKI0-18 & Uncultured bacterium & GQ472352 & 507 & 96 \\
\hline & BKII-34 & Uncultured soil bacterium & DQI28695 & 502 & 99 \\
\hline & BK3-16 & Uncultured soil bacterium & DQI 28804 & 502 & 99 \\
\hline & BK I0-44, BK6-30 & Uncultured soil bacterium & DQI54416 & 507 & $95-94$ \\
\hline & A43 & Uncultured soil bacterium & DQI54590 & 507 & 96 \\
\hline & BKI2-32 & Uncultured soil bacterium & GU3756I4 & 507 & 99 \\
\hline & D34 & Uncultured Verrucomicrobia bacterium & AY874III & 507 & 97 \\
\hline & BK9-29 & Uncultured Verrucomicrobia bacterium & DQ8280I3 & 509 & 92 \\
\hline & BK4-48, BK9-28 & Uncultured Verrucomicrobia bacterium & DQ828099 & 507 & 98 \\
\hline & BC8-II, BK6-9 & Uncultured Verrucomicrobia bacterium & DQ828726 & 507 & 95 \\
\hline & $\mathrm{BCl0}-47$ & Uncultured Verrucomicrobia bacterium & DQ829116 & 502 & 100 \\
\hline & BC7-I5, BK5-38 & Uncultured Verrucomicrobia bacterium & DQ829188 & 507 & $97-96$ \\
\hline & A7 & Uncultured Verrucomicrobia bacterium & DQ829377 & 501 & 98 \\
\hline & BK6-2 & Uncultured Verrucomicrobia bacterium & EFI88508 & 507 & 94 \\
\hline & BK4-II & Uncultured Verrucomicrobia bacterium & EF4I7730 & 491 & 97 \\
\hline & BC6-47 & Uncultured Verrucomicrobia bacterium & EF662304 & 507 & 95 \\
\hline & BK6-23 & Uncultured Verrucomicrobium sp & FM86630I & 506 & 99 \\
\hline & BC5-18 & Unidentified eubacterium & AF0I008I & 507 & 98 \\
\hline Actinobacteria & A50 & Arthrobacter sp. & AY56I60I & 467 & 99 \\
\hline \multirow[t]{22}{*}{87 clones } & $\mathrm{A} 28, \mathrm{~A} 52$ & Bacterium Ellin 6023 & AY234675 & 469 & 98 \\
\hline & BC8-20 & Dactylosporangium salmoneum & FJ973607 & 466 & 96 \\
\hline & BC9-28, ВС9-43 & Kibdelosporangium albatum & NR_025570 & 463 & 97 \\
\hline & BC4-II & Micromonospora sp & EU437793 & 461 & 95 \\
\hline & C53 & Nocardioides oleivorans & AB365060 & 465 & 98 \\
\hline & BC9-2I & Nonomuraea maheshkhaliensis & EU74II90 & 460 & 99 \\
\hline & BK5-36 & Rhodococcus kunmingensis & DQ997045 & 463 & 100 \\
\hline & BK3-47 & Streptomyces argenteolus & FJ486449 & 442 & 100 \\
\hline & BC5-45 & Streptomyces sp & FJ857945 & 463 & 98 \\
\hline & BKI0-38 & Uncultured Acidimicrobiales bacterium & FMI75217 & 469 & 99 \\
\hline & $\mathrm{BCII}-33$ & Uncultured Actinobacteria bacterium & AY922063 & 466 & 95 \\
\hline & BC5-9, BK6-II & Uncultured actinobacterium & DQ827792 & 457 & 99 \\
\hline & BC3-43, BK3-50 & Uncultured actinobacterium & DQ827848 & 471 & 97 \\
\hline & BKII -47 & Uncultured actinobacterium & DQ827876 & 497 & 99 \\
\hline & $\mathrm{F} 4$ & Uncultured actinobacterium & DQ827895 & 494 & 99 \\
\hline & BC4-3 & Uncultured actinobacterium & DQ828615 & 493 & 99 \\
\hline & BC5-3 & Uncultured actinobacterium & DQ828987 & 427 & 99 \\
\hline & E42 & Uncultured actinobacterium & DQ829467 & 468 & 99 \\
\hline & BK7-2I & Uncultured actinobacterium & DQ82957I & 465 & 100 \\
\hline & $\mathrm{C} 24$ & Uncultured actinobacterium & GQII5620 & 470 & 99 \\
\hline & BKI0-4I & Uncultured bacterium & DQI25885 & 467 & 100 \\
\hline & G68 & Uncultured bacterium & DQ125915 & 469 & 100 \\
\hline
\end{tabular}


Table S2 (Continued)

\begin{tabular}{|c|c|c|c|c|c|}
\hline Phylum & Clone name & Blast match & $\begin{array}{l}\text { Accession } \\
\text { number }\end{array}$ & $\begin{array}{l}\text { I6S rDNA } \\
\text { size (bp) }\end{array}$ & Identity (\%) \\
\hline & BKII-24 & Uncultured bacterium & DQI36|35 & 461 & 99 \\
\hline & BK8-I2 & Uncultured bacterium & EF5079|4 & 462 & 95 \\
\hline & BK8-38 & Uncultured bacterium & EF590054 & 464 & 99 \\
\hline & BKI0-23 & Uncultured bacterium & EUI3249I & 477 & 100 \\
\hline & BCII-4I & Uncultured bacterium & EUI32926 & 470 & 98 \\
\hline & BK7-II & Uncultured bacterium & EUI33I25 & 471 & 98 \\
\hline & BK6-8 & Uncultured bacterium & EUI33I43 & 463 & 95 \\
\hline & BC3-3I & Uncultured bacterium & EU335288 & 474 & 99 \\
\hline & BCI0-29 & Uncultured bacterium & EU3354I2 & 494 & 98 \\
\hline & BK8-27 & Uncultured bacterium & FJ40934I & 470 & 99 \\
\hline & $\mathrm{BC} 6-9$ & Uncultured bacterium & FJ409423 & 494 & 98 \\
\hline & BK5-37, BK5-48 & Uncultured bacterium & FJ478477 & 495 & 97 \\
\hline & E37 & Uncultured bacterium & Fj478608 & 463 & 99 \\
\hline & $\mathrm{BCl} 0-26, \mathrm{BCl} 0-35, \mathrm{BCl} 0-5$, & Uncultured bacterium & FJ4790I4 & 477 & $99-98$ \\
\hline & $\mathrm{BCI}-28, \mathrm{BCI} \mathrm{I}-32, \mathrm{BCl} \mathrm{I}-35$ & & & & \\
\hline & $\mathrm{BCl} 1-45, \mathrm{BCl} 2-19, \mathrm{BCl} 2-25$ & & & & \\
\hline & $\mathrm{BCl} 2-26, \mathrm{BCl} 2-28, \mathrm{BCl} 2-3$ & & & & \\
\hline & $\mathrm{BCl} 2-35, \mathrm{BCI} 2-4, \mathrm{BCI} 2-43$ & & & & \\
\hline & $\mathrm{BCI} 2-45, \mathrm{BCI} 2-46, \mathrm{BC} 4-4$ & & & & \\
\hline & BKI0-2, BKI0-28, BKII-I9, & & & & \\
\hline & BKII-22, BKII-30, BKII-32, & & & & \\
\hline & BKII-33, BKII-43, BKI2-15, & & & & \\
\hline & $\mathrm{BK} 12-42, \mathrm{BCI} 2-44, \mathrm{BCI} 2-7$ & & & & \\
\hline & BK7-31 & & & & \\
\hline & BK6-13 & Uncultured bacterium & $\mathrm{FJ} 479120$ & 477 & 98 \\
\hline & BC4-13 & Uncultured bacterium & FJ479349 & 470 & 98 \\
\hline & E3I & Uncultured bacterium & FJ479510 & 467 & 93 \\
\hline & $\mathrm{F} 40$ & Uncultured bacterium & FJ4795I2 & 470 & 99 \\
\hline & BK4-33 & Uncultured bacterium & $\mathrm{FJ} 479550$ & 466 & 100 \\
\hline & $\mathrm{BCl} 2-32$ & Uncultured bacterium & FJ895064 & 465 & 94 \\
\hline & $\mathrm{C} 38$ & Uncultured bacterium & FN565562 & 471 & 100 \\
\hline & $\mathrm{BC} 5-8$ & Uncultured bacterium & GQ02I45I & 494 & 98 \\
\hline & BKI0-7 & Uncultured bacterium & GQ093936 & 470 & 97 \\
\hline & D3I & Uncultured bacterium & GQ397037 & 470 & 100 \\
\hline & BK4-9 & Uncultured bacterium & GQ860235 & 465 & 95 \\
\hline & BKI0-16 & Uncultured Geodermatophilaceae bacterium & AM936742 & 468 & 98 \\
\hline & $\mathrm{Al} 9, \mathrm{BC} 7-43$ & Uncultured soil bacterium & AY988680 & 471 & 99 \\
\hline & BC3-20 & Uncultured soil bacterium & DQ643694 & 463 & 99 \\
\hline \multirow[t]{2}{*}{ Firmicutes } & A8 & Uncultured bacterium & EF516634 & 492 & 95 \\
\hline & BK5-I4 & Bacillus sp. & GQ386842 & 485 & 100 \\
\hline Planctomycetes & BKI0-29 & Uncultured bacterium & $A B \mid 79502$ & 475 & 86 \\
\hline \multirow[t]{15}{*}{33 clones } & BC7-23 & Uncultured bacterium & AB238007 & 446 & 94 \\
\hline & BK4-12, BK8-34 & Uncultured bacterium & AM945498 & 481 & $98-97$ \\
\hline & E52 & Uncultured bacterium & AY963398 & 480 & 98 \\
\hline & BK7-16 & Uncultured bacterium & DQ4047I9 & 466 & 96 \\
\hline & B62 & Uncultured bacterium & DQ664070 & 466 & 95 \\
\hline & BC $8-40$ & Uncultured bacterium & EF0I8763 & 478 & 97 \\
\hline & BKII-II, BKII-37 & Uncultured bacterium & EF580943 & 454 & 97 \\
\hline & BK4-50 & Uncultured bacterium & EUI3508I & 463 & 98 \\
\hline & $\mathrm{BC} 7-8$ & Uncultured bacterium & EU135I62 & 481 & 97 \\
\hline & BC8- 18 & Uncultured bacterium & EUI35262 & 468 & 98 \\
\hline & BC3-16 & Uncultured bacterium & EU385780 & 505 & 82 \\
\hline & BC4-4I & Uncultured bacterium & EU88II 43 & 485 & 98 \\
\hline & $\mathrm{CI} 5$ & Uncultured bacterium & EU88I25I & 482 & 94 \\
\hline & $\mathrm{G} 12$ & Uncultured bacterium & FJ409382 & 452 & 99 \\
\hline & BC8-26 & Uncultured bacterium & FJ47954I & 463 & 98 \\
\hline
\end{tabular}


Table S2 (Continued)

\begin{tabular}{|c|c|c|c|c|c|}
\hline Phylum & Clone name & Blast match & $\begin{array}{l}\text { Accession } \\
\text { number }\end{array}$ & $\begin{array}{l}\text { I6S rDNA } \\
\text { size (bp) }\end{array}$ & Identity (\%) \\
\hline & BC3-8 & Uncultured bacterium & FJ561539 & 444 & 96 \\
\hline & BK5-40 & Uncultured bacterium & FN434034 & 479 & 99 \\
\hline & BKII-9 & Uncultured bacterium & GQ500843 & 465 & 96 \\
\hline & C59 & Uncultured bacterium & GQ500856 & 450 & 98 \\
\hline & G32 & Uncultured bacterium & GUI72I85 & 478 & 93 \\
\hline & BC8-6 & Uncultured Planctomycetaceae bacterium & AM935629 & 462 & 98 \\
\hline & $\mathrm{A} 23$ & Uncultured Planctomycete & AF27I339 & 475 & 98 \\
\hline & B42 & Uncultured Planctomycete & DQ82872I & 480 & 98 \\
\hline & BC9-13 & Uncultured Planctomycete & EFI88390 & 582 & 93 \\
\hline & BC5-I & Uncultured Planctomycete & DQ334903 & 455 & 95 \\
\hline & B67 & Uncultured Planctomycetes bacterium & CU922082 & 481 & 92 \\
\hline & $\mathrm{G} 23$ & Uncultured soil bacterium & AY989608 & 473 & 96 \\
\hline & BC3-4 & Uncultured soil bacterium & DQI54378 & 463 & 96 \\
\hline & BK7-I & Uncultured soil bacterium & EF455372 & 478 & 99 \\
\hline & E25 & Unidentified bacterium & $\times 64377$ & 476 & 93 \\
\hline Nitrospirae & $\mathrm{C} 32$ & Uncultured bacterium & DQ664I34 & 488 & 99 \\
\hline \multirow[t]{7}{*}{10 clones } & BC9-10, BK8-15 & Uncultured bacterium & FN565533 & 488 & 99 \\
\hline & $\mathrm{BC} 10-32$ & Uncultured bacterium & GQ500740 & 488 & 97 \\
\hline & A40 & Uncultured bacterium & GU359089 & 486 & 100 \\
\hline & GI6 & Uncultured Nitrospirae bacterium & EU374034 & 464 & 97 \\
\hline & $\mathrm{E} 35, \mathrm{BC} 5-28$ & Uncultured Nitrospirae bacterium & FJ535I0I & 488 & 99 \\
\hline & BC8-44 & Uncultured Polyangiaceae bacterium & EF020217 & 497 & 94 \\
\hline & BK8-4 & Uncultured soil bacterium & DQI5445I & 488 & 99 \\
\hline \multirow[t]{4}{*}{ ODI } & A46 & Uncultured bacterium & AY532554 & 483 & 89 \\
\hline & BKI2-40 & Uncultured bacterium & EF5I6449 & 438 & 89 \\
\hline & BKI0-36 & Uncultured candidate division & FJ482I 73 & 488 & 87 \\
\hline & & ODI bacterium & & & \\
\hline \multirow[t]{5}{*}{ OPIO } & $\mathrm{BClO}-\mathrm{I}$ & Uncultured bacterium & EF430426 & 470 & 100 \\
\hline & G67 & Uncultured bacterium & EUI34998 & 453 & 96 \\
\hline & BC5-35 & Uncultured bacterium & GQ859782 & 453 & 96 \\
\hline & D4 & Uncultured bacterium & GUI83929 & 453 & 93 \\
\hline & G54 & Uncultured bacterium & AJ271048 & 450 & 95 \\
\hline \multirow[t]{2}{*}{ OPII } & BC8-28 & Uncultured candidate division & FJ482190 & 438 & 91 \\
\hline & & OPII bacterium & & & \\
\hline \multirow[t]{4}{*}{ TM7 } & BC8-4I & Uncultured bacterium & AM991262 & 533 & 90 \\
\hline & BC9-32 & Uncultured bacterium & FJ478502 & 493 & 96 \\
\hline & BK5-10 & Uncultured bacterium & FN2979I4 & 613 & 94 \\
\hline & BK9-4I & Uncultured bacterium & GQ396865 & 528 & 93 \\
\hline \multirow[t]{2}{*}{ WS3 } & BC6-20 & Uncultured bacterium & DQ828640 & 504 & 99 \\
\hline & BC7-7 & Uncultured soil bacterium & DQI54428 & 505 & 99 \\
\hline Gemmatimonadetes & G35 & Uncultured bacterium & AF432633 & 469 & 98 \\
\hline \multirow[t]{15}{*}{34 clones } & BK6-27 & Uncultured bacterium & EF393220 & 469 & 96 \\
\hline & BKI2-II & Uncultured bacterium & EUI34803 & 470 & 93 \\
\hline & BK8-28 & Uncultured bacterium & EUI 34827 & 472 & 95 \\
\hline & BC6-32 & Uncultured bacterium & EUI 34844 & 476 & 94 \\
\hline & BC8-2I & Uncultured bacterium & EUI 34844 & 470 & 98 \\
\hline & BK6-4 & Uncultured bacterium & EUI60218 & 461 & 98 \\
\hline & BK I0-24, BK7-42 & Uncultured bacterium & EU335213 & 493 & 98 \\
\hline & B34 & Uncultured bacterium & EU335434 & 498 & 99 \\
\hline & BCII-24, BC9-39, BK8-5 & Uncultured bacterium & EU88II6I & 472 & 100 \\
\hline & $\mathrm{EI} 3$ & Uncultured bacterium & FN56552I & 470 & 100 \\
\hline & $\mathrm{C} 8$ & Uncultured bacterium & GQ263I25 & 475 & 98 \\
\hline & BK9-6 & Uncultured bacterium & GQ40282I & 468 & 89 \\
\hline & $\mathrm{BC} 10-27$ & Uncultured Gemmatimonadales bacterium & FM209166 & 468 & 96 \\
\hline & G38 & Uncultured Gemmatimonadales bacterium & AY217502 & 493 & 99 \\
\hline & BK7-19 & Uncultured Gemmatimonadales bacterium & AY921858 & 475 & 99 \\
\hline
\end{tabular}


Table S2 (Continued)

\begin{tabular}{|c|c|c|c|c|c|}
\hline Phylum & Clone name & Blast match & $\begin{array}{l}\text { Accession } \\
\text { number }\end{array}$ & $\begin{array}{l}\text { I6S rDNA } \\
\text { size (bp) }\end{array}$ & Identity (\%) \\
\hline & E9 & Uncultured Gemmatimonadales bacterium & DQ45I476 & 472 & 93 \\
\hline & BC6-37 & Uncultured Gemmatimonadales bacterium & DQ828232 & 482 & 95 \\
\hline & BKII-I7, BK3-43 & Uncultured Gemmatimonadales bacterium & EFOI9245 & 475 & 99 \\
\hline & BC9-I & Uncultured Gemmatimonadales bacterium & EF6640I2 & 386 & 97 \\
\hline & BK3-30 & Uncultured Gemmatimonas sp & FJ946547 & 468 & 97 \\
\hline & BK6-43 & Uncultured soil bacterium & DQI 28528 & 470 & 94 \\
\hline & BC6-25, BK9-19 & Uncultured soil bacterium & DQI 28836 & 482 & 98 \\
\hline & BK8-23 & Uncultured soil bacterium & DQI 28836 & 479 & 93 \\
\hline & BK7-10 & Uncultured soil bacterium & DQI54587 & 472 & 99 \\
\hline & $\mathrm{BCII}-15$ & Uncultured soil bacterium & EF540397 & 467 & 97 \\
\hline & $\mathrm{BI} 2, \mathrm{~B} 4$ & Uncultured soil bacterium & FJ621029 & 493 & 97 \\
\hline & BC9-20 & Uncultured soil bacterium & FJ621069 & 469 & 99 \\
\hline Chloroflexi & BK5-43, BK7-26 & Uncultured Anaerolineae bacterium & AM93574I & 470 & $99-98$ \\
\hline \multirow[t]{29}{*}{43 clones } & $\mathrm{BCl} 2-18, \mathrm{BC} 6-13$ & Uncultured bacterium & AB240474 & 470 & 100 \\
\hline & BKIII-36 & Uncultured bacterium & AMI58349 & 444 & 95 \\
\hline & G2 & Uncultured bacterium & AMI 62480 & 470 & 97 \\
\hline & $\mathrm{BCIO}-12$ & Uncultured bacterium & AY221060 & 461 & 98 \\
\hline & D43 & Uncultured bacterium & DQ067035 & 470 & 97 \\
\hline & BC4-44, F46 & Uncultured bacterium & DQ093879 & 470 & 99 \\
\hline & $\mathrm{BCl} 2-34$ & Uncultured bacterium & DQ444024 & 470 & 99 \\
\hline & BK3-7 & Uncultured bacterium & DQ444I05 & 470 & 100 \\
\hline & BK7-9 & Uncultured bacterium & DQ828928 & 468 & 97 \\
\hline & BC5-4, BC8-2 & Uncultured bacterium & EF667828 & 470 & 99 \\
\hline & BC4-27 & Uncultured bacterium & EUI3402I & 444 & 94 \\
\hline & BK3-28 & Uncultured bacterium & EUI34025 & 470 & 98 \\
\hline & BC4-26, EI8 & Uncultured bacterium & EUI34065 & 451 & $93-92$ \\
\hline & BK4-34 & Uncultured bacterium & EUI34I47 & 470 & 99 \\
\hline & BKII-20 & Uncultured bacterium & EU280640 & 470 & 99 \\
\hline & $\mathrm{BCI} 2-24$ & Uncultured bacterium & EU33520I & 448 & 95 \\
\hline & BK7-I7 & Uncultured bacterium & FJI750II & 470 & 99 \\
\hline & $\mathrm{BC} 7-4$ & Uncultured bacterium & FJ4I5684 & 470 & 98 \\
\hline & BC4-20 & Uncultured bacterium & FJ478597 & 470 & 99 \\
\hline & BKI0-3I, BKI0-32 & Uncultured bacterium & FJ478654 & 470 & 98 \\
\hline & $\mathrm{BCI}-16, \mathrm{BCI} 2-48$ & Uncultured bacterium & FJ479268 & 470 & $99-98$ \\
\hline & ВC3-15, BC7-39, BK6-38 & & & & \\
\hline & BC7-27 & Uncultured bacterium & GQ85993। & 470 & 98 \\
\hline & BK5-22 & Uncultured bacterium & GU325870 & 470 & 98 \\
\hline & $\mathrm{BC} 10-40$ & Uncultured bacterium & GU390324 & 470 & 99 \\
\hline & BC8-34, BC8-35, BK6-5 & Uncultured Chloroflexi bacterium & EF22077I & 470 & 99 \\
\hline & BK5-23 & Uncultured Chloroflexi bacterium & GQ26709I & 471 & 90 \\
\hline & BC6-43 & Uncultured soil bacterium & DQI54387 & 470 & 99 \\
\hline & BC4-2, BC4-40, BK5-4I & Uncultured soil bacterium & DQI54570 & 470 & $100-99$ \\
\hline \multirow[t]{2}{*}{ Cyanobacteria } & BC4-I5 & Uncultured bacterium & GQ109II4 & 438 & 100 \\
\hline & $\mathrm{BCl} 2-37$ & Uncultured bacterium & FJ390538 & 438 & 100 \\
\hline Spirochaetes & $\mathrm{BCl} 2-22$ & Turneriella parva & AY398688 & 445 & 93 \\
\hline Unclassified bacteria & BK3-II & Mortierella verticillata & AY8632II & 409 & 94 \\
\hline \multirow[t]{9}{*}{238 clones } & A5I & Uncultured Acidobacteria bacterium & AM935472 & 506 & 96 \\
\hline & $\mathrm{BCI} 0-34, \mathrm{BK} 4-24$ & Uncultured Acidobacteria bacterium & DQ827894 & 506 & $94-93$ \\
\hline & BC4-48 & Uncultured Acidobacteria bacterium & DQ828059 & 506 & 97 \\
\hline & BC6-15, BC6-18 & Uncultured Acidobacteria bacterium & DQ828073 & 506 & 97 \\
\hline & $\mathrm{BCI}-4, \mathrm{BK} 6-3$ & Uncultured Actinobacteria bacterium & AY922024 & 493 & 99 \\
\hline & BC5-40 & Uncultured bacterium & AB237977 & 462 & 97 \\
\hline & $\mathrm{A} 2 \mathrm{I}$ & Uncultured bacterium & AF234II8 & 485 & 93 \\
\hline & BC9-30 & Uncultured bacterium & AF392792 & 490 & 94 \\
\hline & $\mathrm{F} 18$ & Uncultured bacterium & AF432840 & 505 & 98 \\
\hline
\end{tabular}


Table S2 (Continued)

\begin{tabular}{|c|c|c|c|c|c|}
\hline Phylum & Clone name & Blast match & $\begin{array}{l}\text { Accession } \\
\text { number }\end{array}$ & $\begin{array}{l}\text { I6S rDNA } \\
\text { size (bp) }\end{array}$ & Identity (\%) \\
\hline & BC3-2 & Uncultured bacterium & AM085466 & 492 & 95 \\
\hline & $\mathrm{A} 26$ & Uncultured bacterium & AMI8I963 & 501 & 83 \\
\hline & BK4-16 & Uncultured bacterium & AM4I0034 & 492 & 95 \\
\hline & BCII-I4, BKI0-26 & Uncultured bacterium & AM90567I & 500 & $96-95$ \\
\hline & BC7-25, BC8-46 & Uncultured bacterium & AM997454 & 455 & $85-84$ \\
\hline & C55 & Uncultured bacterium & AY221070 & 445 & 98 \\
\hline & BKI2-23 & Uncultured bacterium & DQ0I79II & 459 & 97 \\
\hline & BK4-30 & Uncultured bacterium & DQ310742 & 484 & 95 \\
\hline & F52 & Uncultured bacterium & DQ444020 & 457 & 95 \\
\hline & BCII-8 & Uncultured bacterium & DQ444III & 480 & 89 \\
\hline & BK6-12 & Uncultured bacterium & DQ51003I & 491 & 90 \\
\hline & $\mathrm{C} 35, \mathrm{C} 54$ & Uncultured bacterium & DQ664088 & 481 & 98 \\
\hline & BC4-33 & Uncultured bacterium & DQ79|253 & 488 & 78 \\
\hline & BK $10-4$ & Uncultured bacterium & DQ828I37 & 463 & 95 \\
\hline & BK4-2, D40 & Uncultured bacterium & DQ828297 & 453 & 94 \\
\hline & BC9-35 & Uncultured bacterium & DQ829107 & 477 & 93 \\
\hline & E4 & Uncultured bacterium & DQ829487 & 505 & 99 \\
\hline & $\mathrm{C} 29$ & Uncultured bacterium & DQ90680I & 482 & 95 \\
\hline & G6I & Uncultured bacterium & DQ906875 & 506 & 95 \\
\hline & BC4-23, BC5-32 & Uncultured bacterium & EF0I8468 & 462 & $99-98$ \\
\hline & BK7-24 & Uncultured bacterium & EFOI9124 & 455 & 98 \\
\hline & BC5-36 & Uncultured bacterium & EFOI 9253 & 470 & 91 \\
\hline & BK5-50 & Uncultured bacterium & EF020070 & 501 & 98 \\
\hline & BC7-3 & Uncultured bacterium & EF020290 & 433 & 94 \\
\hline & BC5-4I & Uncultured bacterium & EF393365 & 456 & 98 \\
\hline & D7 & Uncultured bacterium & EF494294 & 475 & 88 \\
\hline & E40 & Uncultured bacterium & EF5I5989 & 456 & 96 \\
\hline & BK $10-46$ & Uncultured bacterium & EF516008 & 496 & 93 \\
\hline & BK6-48 & Uncultured bacterium & EF516242 & 462 & 97 \\
\hline & BK4-8 & Uncultured bacterium & EF5I 6747 & 433 & 91 \\
\hline & B8 & Uncultured bacterium & EF588346 & 473 & 98 \\
\hline & BCI0-17, BC6-44 & Uncultured bacterium & EF632929 & 482 & 96 \\
\hline & BKI2-38 & Uncultured bacterium & EU015II2 & 446 & 90 \\
\hline & A58 & Uncultured bacterium & EU043640 & 494 & 96 \\
\hline & $\mathrm{A} 3 \mathrm{I}$ & Uncultured bacterium & EU131926 & 506 & 94 \\
\hline & DIO & Uncultured bacterium & EUI32345 & 505 & 98 \\
\hline & BC6-1I & Uncultured bacterium & EUI32690 & 493 & 98 \\
\hline & BK8-19 & Uncultured bacterium & EUI32730 & 493 & 100 \\
\hline & BC3-36 & Uncultured bacterium & EUI 32994 & 480 & 95 \\
\hline & BKII-IO & Uncultured bacterium & EU133191 & 493 & 99 \\
\hline & $\mathrm{BCI}$ I-42, BCI2-29, & Uncultured bacterium & EUI33988 & 449 & $95-94$ \\
\hline & $\mathrm{BCI} 2-38, \mathrm{BCI} 2-47$ & & & & \\
\hline & BC3-24 & Uncultured bacterium & EUI340I2 & 453 & 98 \\
\hline & BC5-29 & Uncultured bacterium & EUI340I3 & 455 & 98 \\
\hline & BKII-42 & Uncultured bacterium & EU134018 & 455 & 93 \\
\hline & BK4-23 & Uncultured bacterium & EUI34026 & 463 & 97 \\
\hline & BC4-42, BC7-19 & Uncultured bacterium & EUI34079 & 448 & $97-95$ \\
\hline & BC3-32, BK5-7 & Uncultured bacterium & EUI34I26 & 485 & $95-93$ \\
\hline & BK6-37, BK7-28, EI, EIO & Uncultured bacterium & EUI34I26 & 462 & $100-97$ \\
\hline & BC7-I, BK8-17 & Uncultured bacterium & EUI34I53 & 459 & 97 \\
\hline & $\mathrm{A} 22, \mathrm{~B} 69$ & Uncultured bacterium & EUI3423I & 449 & $96-95$ \\
\hline & BC9-22 & Uncultured bacterium & EU1343I5 & 512 & 97 \\
\hline & F8 & Uncultured bacterium & EUI3449I & 504 & 95 \\
\hline & BK5-32 & Uncultured bacterium & EUI34688 & 482 & 88 \\
\hline & BC4-19 & Uncultured bacterium & EUI348I6 & 562 & 95 \\
\hline
\end{tabular}


Table S2 (Continued)

\begin{tabular}{|c|c|c|c|c|c|}
\hline Phylum & Clone name & Blast match & $\begin{array}{l}\text { Accession } \\
\text { number }\end{array}$ & $\begin{array}{l}\text { I6S rDNA } \\
\text { size (bp) }\end{array}$ & Identity (\%) \\
\hline & BKIII-7 & Uncultured bacterium & EUI34836 & 493 & 96 \\
\hline & BC9-I4, BK4-6 & Uncultured bacterium & EUI35006 & 452 & 98 \\
\hline & BC8-23 & Uncultured bacterium & EUI 35008 & 467 & 90 \\
\hline & BK7-15 & Uncultured bacterium & EUI 35025 & $47 \mid$ & 90 \\
\hline & BC8-16 & Uncultured bacterium & EUI35055 & 446 & 95 \\
\hline & BC8-30 & Uncultured bacterium & EUI35I95 & 489 & 96 \\
\hline & $\mathrm{BCII}-30$ & Uncultured bacterium & EUI 35283 & 451 & 96 \\
\hline & $\mathrm{BCI} 2-40$ & Uncultured bacterium & EUI 35294 & 519 & 99 \\
\hline & BK3-10 & Uncultured bacterium & EUI 35325 & 496 & 93 \\
\hline & A38 & Uncultured bacterium & EUI35338 & 505 & 96 \\
\hline & $\mathrm{Cl} 3$ & Uncultured bacterium & EUI 35355 & 500 & 94 \\
\hline & A3, DI5 & Uncultured bacterium & EUI35357 & 506 & $97-96$ \\
\hline & $\mathrm{BCI}-23$ & Uncultured bacterium & EUI 60080 & 503 & 93 \\
\hline & $B K \mid 2-30$ & Uncultured bacterium & EU335I77 & 495 & 96 \\
\hline & $\mathrm{F} 29$ & Uncultured bacterium & EU335213 & 493 & 98 \\
\hline & BC4-16, BC5-37, BK5-13 & Uncultured bacterium & EU335214 & 506 & $98-97$ \\
\hline & BC6-3I & Uncultured bacterium & EU33527I & 488 & 98 \\
\hline & BC3-27 & Uncultured bacterium & EU3354I3 & 464 & 96 \\
\hline & B3 & Uncultured bacterium & EU335434 & 495 & 97 \\
\hline & BKI0-22 & Uncultured bacterium & EU385780 & 506 & 82 \\
\hline & BI5 & Uncultured bacterium & EU386030 & 616 & 95 \\
\hline & B53 & Uncultured bacterium & EU386045 & 462 & 92 \\
\hline & G47 & Uncultured bacterium & EU557952 & 455 & 98 \\
\hline & BC3-28 & Uncultured bacterium & EU644764 & 537 & 85 \\
\hline & $\mathrm{BCI}-26$ & Uncultured bacterium & EU669607 & 460 & 92 \\
\hline & BC6-39 & Uncultured bacterium & EU680389 & 482 & 97 \\
\hline & E36 & Uncultured bacterium & EU88II32 & 505 & 97 \\
\hline & $B C|I-3|$ & Uncultured bacterium & EU88II5I & 484 & 98 \\
\hline & A9 & Uncultured bacterium & EU88II54 & 505 & 98 \\
\hline & BC8-22 & Uncultured bacterium & EU881212 & 445 & 98 \\
\hline & G9 & Uncultured bacterium & EU88I279 & 467 & 99 \\
\hline & A42 & Uncultured bacterium & EU88I343 & 505 & 98 \\
\hline & BCII-2I, BC4-22, BKII-5 & Uncultured bacterium & EU88I358 & 485 & 94 \\
\hline & $\mathrm{B} 19$ & Uncultured bacterium & EU9|7737 & 471 & 88 \\
\hline & BK3-6 & Uncultured bacterium & FJ409340 & 474 & 93 \\
\hline & BK8-20 & Uncultured bacterium & FJ409340 & 471 & 77 \\
\hline & $\mathrm{G} 25$ & Uncultured bacterium & FJ409355 & 453 & 100 \\
\hline & E34 & Uncultured bacterium & FJ478646 & 505 & 97 \\
\hline & BC7-12 & Uncultured bacterium & FJ478663 & 461 & 96 \\
\hline & $\mathrm{F} 45$ & Uncultured bacterium & FJ478699 & 444 & 95 \\
\hline & BKI0-6 & Uncultured bacterium & FJ478736 & 431 & 92 \\
\hline & BC6-I & Uncultured bacterium & FJ478869 & 505 & 99 \\
\hline & BKII-35 & Uncultured bacterium & FJ4790I4 & 477 & 97 \\
\hline & BC4-47 & Uncultured bacterium & FJ479I08 & 467 & 94 \\
\hline & BK5-8, F4I & Uncultured bacterium & FJ479108 & 467 & $98-97$ \\
\hline & B59 & Uncultured bacterium & FJ479I77 & 466 & 94 \\
\hline & BK7-35 & Uncultured bacterium & FJ479204 & 472 & 89 \\
\hline & BK8-I & Uncultured bacterium & FJ4793I7 & 493 & 99 \\
\hline & BK5-27 & Uncultured bacterium & FJ479355 & 450 & 98 \\
\hline & GI8 & Uncultured bacterium & FJ479422 & 505 & 97 \\
\hline & E8 & Uncultured bacterium & FJ592933 & 483 & 97 \\
\hline & GII & Uncultured bacterium & FJ6I5979 & 446 & 99 \\
\hline & A44 & Uncultured bacterium & FJ625343 & 491 & 92 \\
\hline & BKI $2-25$ & Uncultured bacterium & FJ6495II & 463 & 85 \\
\hline & BC5-17 & Uncultured bacterium & FJ7488I5 & 495 & 89 \\
\hline & D46 & Uncultured bacterium & FJ902567 & 478 & 94 \\
\hline & BKI0-19 & Uncultured bacterium & FM956309 & 490 & 87 \\
\hline
\end{tabular}


Table S2 (Continued)

\begin{tabular}{|c|c|c|c|c|c|}
\hline Phylum & Clone name & Blast match & $\begin{array}{l}\text { Accession } \\
\text { number }\end{array}$ & $\begin{array}{l}\text { I6S rDNA } \\
\text { size (bp) }\end{array}$ & Identity (\%) \\
\hline & BK3-34 & Uncultured bacterium & FM956978 & 469 & 92 \\
\hline & BC4-24 & Uncultured bacterium & FN434032 & 463 & 90 \\
\hline & BC7-18 & Uncultured bacterium & GQ0I543I & 465 & 98 \\
\hline & BK6-46 & Uncultured bacterium & GQ339116 & 457 & 98 \\
\hline & BKI2-33 & Uncultured bacterium & GQ347I52 & 453 & 85 \\
\hline & G36 & Uncultured bacterium & GQ359399 & 462 & 86 \\
\hline & DI & Uncultured bacterium & GQ376896 & 493 & 98 \\
\hline & $\mathrm{C} 47$ & Uncultured bacterium & GQ376969 & 506 & 98 \\
\hline & B23, D45 & Uncultured bacterium & GQ376998 & 470 & $99-98$ \\
\hline & $\mathrm{C} 62$ & Uncultured bacterium & GQ402727 & 505 & 87 \\
\hline & BC8- 10 & Uncultured bacterium & GQ402788 & 481 & 97 \\
\hline & BCI0-9, BK9-25 & Uncultured bacterium & GQ472345 & 514 & 94 \\
\hline & $B C 7-13$ & Uncultured bacterium & GQ5007I5 & 484 & 92 \\
\hline & BKI0-34 & Uncultured bacterium & GQ859793 & 488 & 97 \\
\hline & $\begin{array}{l}\text { BKIII-39, BKII - } 40 \text {, } \\
\text { BK8-I3 }\end{array}$ & Uncultured bacterium & GQ8598I7 & 462 & 96 \\
\hline & G27 & Uncultured bacterium & GQ860162 & 502 & 97 \\
\hline & BKII-I8 & Uncultured bacterium & GQ860I82 & 463 & 95 \\
\hline & $\mathrm{FI7}$ & Uncultured bacterium & GU326072 & 475 & 92 \\
\hline & BC6-36 & Uncultured bacterium & GU366869 & 504 & 93 \\
\hline & F30, F39 & Uncultured candidate division & AYI92283 & 484 & 92 \\
\hline & & SAM bacterium & & & \\
\hline & BK7-2, BK7-3, CI4 & Uncultured candidate division & AM936223 & 503 & $99-98$ \\
\hline & & SPAM bacterium & & & \\
\hline & $\mathrm{BCII}-\mathrm{I} 2$ & Uncultured candidate division & AM935389 & 466 & 99 \\
\hline & & WS3 bacterium & & & \\
\hline & BC5-23 & Uncultured Chloroflexi bacterium & EFI 88525 & 459 & 96 \\
\hline & C3I, C33 & Uncultured Chloroflexi bacterium & FJI75075 & 455 & 91 \\
\hline & BK7-5 & Uncultured Chloroflexi bacterium & FJ535096 & 463 & 98 \\
\hline & BKI2-34 & Uncultured Cystobacteraceae bacterium & FMI 76285 & 487 & 92 \\
\hline & $\mathrm{BC} 8-32$ & Uncultured earthworm cast bacterium & AY037734 & 470 & 87 \\
\hline & BKI0-37, BK I0-40 & Uncultured Firmicutes bacterium & EF662862 & 507 & 97 \\
\hline & $\mathrm{BC} 6-33$ & $\begin{array}{l}\text { Uncultured Gemmatimonadetes } \\
\text { bacterium }\end{array}$ & AY795667 & 517 & 94 \\
\hline & BC9-26 & $\begin{array}{l}\text { Uncultured Gemmatimonadetes } \\
\text { bacterium }\end{array}$ & AY921682 & 499 & 96 \\
\hline & BC4-45, BK4-7 & $\begin{array}{l}\text { Uncultured Gemmatimonadetes } \\
\text { bacterium }\end{array}$ & AY921705 & 486 & $94-93$ \\
\hline & B60, DI2, G34 & $\begin{array}{l}\text { Uncultured Gemmatimonadetes } \\
\text { bacterium }\end{array}$ & DQ828970 & 497 & 96 \\
\hline & BC8-12 & Uncultured Geothermobacter sp. & FMI 76362 & 462 & 98 \\
\hline & BK5-34 & Uncultured Methylothermus sp. & FMI 76282 & 435 & 97 \\
\hline & BK5-44 & Uncultured organism & GQ39|452 & 441 & 91 \\
\hline & BK8-10 & Uncultured planctomycete & AF27I338 & 468 & 82 \\
\hline & BC9-5 & Uncultured planctomycete & AY921932 & 446 & 99 \\
\hline & BC4-29 & Uncultured planctomycete & EF447090 & 489 & 96 \\
\hline & $B C|0-2|$ & Uncultured prokaryote & GU208269 & 506 & 97 \\
\hline & BC7-38 & Uncultured prokaryote & GU208285 & 434 & 98 \\
\hline & BC4-2I & Uncultured proteobacterium & EU297II6 & 447 & 97 \\
\hline & BC7-5, BC7-6 & Uncultured proteobacterium & EU29768I & 434 & $98-97$ \\
\hline & B37 & Uncultured soil bacterium & AF507682 & 451 & 86 \\
\hline & B39 & Uncultured soil bacterium & AF507700 & 466 & 93 \\
\hline & BC8-45 & Uncultured soil bacterium & AY037564 & 471 & 92 \\
\hline & BKI2-35 & Uncultured soil bacterium & AY037564 & 471 & 99 \\
\hline & BC7-40 & Uncultured soil bacterium & AY493960 & 457 & 89 \\
\hline & BKI0-30 & Uncultured soil bacterium & AY988880 & 480 & 94 \\
\hline & $\mathrm{BCI} 2-17$ & Uncultured soil bacterium & AY989142 & 489 & 90 \\
\hline & $\mathrm{B} 18$ & Uncultured soil bacterium & AY989303 & 505 & 97 \\
\hline
\end{tabular}


Table S2 (Continued)

\begin{tabular}{|c|c|c|c|c|c|}
\hline Phylum & Clone name & Blast match & $\begin{array}{l}\text { Accession } \\
\text { number }\end{array}$ & $\begin{array}{l}\text { I6S rDNA } \\
\text { size (bp) }\end{array}$ & Identity (\%) \\
\hline & BKI2-16 & Uncultured soil bacterium & AY989453 & 501 & 95 \\
\hline & BCII-9, BC8-47, & Uncultured soil bacterium & DQI28836 & 479 & $93-92$ \\
\hline & E39, BKII-46 & & & & \\
\hline & $\begin{array}{l}\text { BC5-13, BKI0-10, } \\
\text { BKI2-2I, BK7-4 }\end{array}$ & Uncultured soil bacterium & DQI28836 & 482 & $98-97$ \\
\hline & BK8-18 & Uncultured soil bacterium & DQI54470 & 503 & 97 \\
\hline & $\mathrm{C} 2 \mathrm{I}$ & Uncultured soil bacterium & DQ298008 & 477 & 87 \\
\hline & B68 & Uncultured soil bacterium & EU86I85I & 455 & 90 \\
\hline & BKI0-I7, E2। & Uncultured soil bacterium & FJ621029 & 493 & 98 \\
\hline & D44 & Uncultured soil bacterium & GU082820 & 446 & 99 \\
\hline & BC8-39 & Uncultured soil bacterium & GU375I42 & 455 & 98 \\
\hline & E6 & Uncultured soil bacterium & GU375I9I & 503 & 88 \\
\hline & BK4-25 & Uncultured soil bacterium & GU375444 & 500 & 98 \\
\hline & BK6-16 & Uncultured soil bacterium & GU375444 & 500 & 95 \\
\hline & ВCI0-3I, BCI0-4I & Uncultured soil bacterium & GU375616 & 486 & 97 \\
\hline & BC3-22 & Uncultured soil bacterium & GU375628 & 579 & 91 \\
\hline & E32 & Uncultured soil bacterium & GU375654 & 489 & 96 \\
\hline & BK5-28 & Uncultured Thiorhodospira sp & FMI 77025 & 483 & 95 \\
\hline & BKII-I4 & Unidentified bacterium & $E F 220517$ & 503 & 99 \\
\hline & BC3-13 & Unidentified bacterium & EF605627 & 445 & 92 \\
\hline & BK8-16 & Unidentified bacterium & EF605970 & 470 & 97 \\
\hline & BK9-24 & Unidentified bacterium & EF605978 & 443 & 94 \\
\hline
\end{tabular}

Note: ${ }^{1} \mid 6 S$ rDNA gene sequences with $>97 \%$ similarity are considered to be the same species in phylogenetic position.

Abbreviation: bp, base pair.

\section{Publish your work in this journal}

The International Journal of Wine Research is an international, peer-reviewed open-access, online journal focusing on all scientific aspects of wine, including: vine growing; wine elaboration; human interaction with wine; and health aspects of wine. The journal provides an open access platform for the reporting of evidence based studies on these topics. The manuscript management system is completely online and includes a very quick and fair peer-review system, which is all easy to use. Visit http://www.dovepress.com/testimonials.php to read real quotes from some of our published authors. 